\title{
The Production, Distribution and Fate of Yessotoxins, Taking the northern Yellow Sea of China for Example
}

\author{
Renyan Liu ${ }^{1, *}$, Lei Liu ${ }^{1}$, Yanlong Xu ${ }^{1}$, Lin Yang ${ }^{1}$, Yubo Liang ${ }^{1}$, Dongmei Li ${ }^{1}$, \\ Ning Wei ${ }^{1}$, Decai Yang ${ }^{2}$, Ye Cong ${ }^{2}$ \\ ${ }^{1}$ National Marine Environmental Monitoring Center, China \\ ${ }^{2}$ School of Life Science and Biotechnology, Dalian University of Technology, China
}

Copyright $\mathrm{O} 2016$ by authors, all rights reserved. Authors agree that this article remains permanently open access under the terms of the Creative Commons Attribution License 4.0 International License

\begin{abstract}
Yessotoxins(YTXs) is a phycotoxin produced by phytoplankton that has been reported as cardiotoxic and have been detected in microalgae and/or bivalve molluscs in many countries. Their presence in shellfish was discovered due to their high acute toxicity in mice after i.p. injection of lipophilic extracts. YTXs in sediment, seawater, plankton and shellfish in the northern Yellow Sea of China were investigated. The least YTXs level and the lowest detection rate occurred in sediment, while a maximum level of 24.6ng/L appeared in the plankton; the change trend in seawater was similar to that in plankton. YTXs in mussel and Chlamys farreri were all higher than it in oyster. The three dinoflagellates which can produce YTXs, Protoceratium reticulatum, Lingulodinium polyedrum and Gonyaulax spinifera, have been all found. The abundance change of toxic dinoflagellates was consistent with YTXs in plankton, seawater and shellfishes. $P$. reticulatum is one of the main microalgae which can produce YTXs in the northern Yellow Sea coast; this $P$. reticulatum have been separated from seawater, and its ecological features of production YTXs have been studied. The distribution of YTXs in particulate matters, seawater, and shellfishes has also been studied by the experiments of feeding trial to Patinopecten yessoensis, Chlamys farreri and mussel. The more YTXs would distribute in particles and seawater, while in shellfishes there was the smallest proportion, only $1 \%$ around. According to the results in this paper, the ecological functions of the northern Yellow Sea coast as aquiculture area was still good, but the potential ecological risk of YTXs cannot be ignored.
\end{abstract}

Keywords Yessotoxin, Protoceratium Reticulatum, Shellfish, Production and Distribution

\section{Introduction}

Yessotoxins (YTXs) is a group of disulfated polyether toxins produced by marine dinoflagellate which was first separated from Patinopecten yessoensis of Japanese Mutsu Bay in 1986[1]. Until now, Norway, Italy, New Zealand, Chile, Japan, Russia, Ireland, America, China and other countries have also detected YTXs in shellfish and algae[2,3,4,5].There are reports on YTXs which can cause damages to cells, cardiac muscle, liver and pancreas and neuronal tissue[5,6,7]. YTXs accumulate in shellfish and have high acute toxicity to mice by intraperitoneal injection, and YTXs have been found to be potent cytotoxins [8]. A regulatory level of $3.75 \mathrm{mg}$ YTX equivalents $/ \mathrm{kg}$ in shellfish has been established in Europe and some countries. Dozens of YTXs homologues had been found in phytoplankton and shellfishes $[1,4,9,10]$.

As reported, there were three dinoflagellates that can produce YTXs: Protoceratium reticulatum [5,11,12,13], Lingulodinium polyedrum $[14,15]$ and Gonyaulax spinifera $[16,17]$. P. reticulatum had ever happened bloom in New Zealand (30000 cell/L) and Norway (2200 cell/L). At the same time, YTX with high concentration was detected in shellfishes [18]. P. reticulatum from different Japanese coast can produce different structures of YTXs while some cannot produce YTXs [19]. Three dinoflagellates were also found in Chinese coastal waters [2, 20]. As report shows, the degradation of YTXs was fairly slow, it can exist in shellfish for at least 5 months, and YTXs can be residual for a long time [21]. There is little known about the production, degradation, distribution and fate of YTXs in the whole ecological chain.

Harmful Algal Bloom (HAB), not only the frequency, intensity, but geographic distribution of such blooms have increased worldwide, which lead to economic losses and major environmental problems such as ecosystem disruptions. In addition, toxic microalgae produce toxic metabolites or bioactive compounds, which have an important impact on both human health and shellfish industries.

In recent years, HAB events are increasing in frequency and intensity in China. YTXs have been found in several main economic species of shellfishes coming from 
aquiculture areas of the northern Yellow Sea of China. There were three structures detected: yessotoxin (YTX), 45-OH-YTX and homo-YTX [2]. Little is known about its producer in there, and the distribution and fate yet. The northern Yellow Sea of China is located in the northeast of China. Along the coast, there is main aquaculture area for about ten species of economic bivalve mollusks, including $P$. yessoensis, Chlamys farreri, and other scallop, mussel, oyster, and clam.

The aim of this work was to perform the study of the ecological features of $P$. reticulatum and the distribution of YTXs in seawater, shellfishes and sediment; by feeding trials in laboratory, to simulate the distribution and fate of yessotoxins in ecosystem.

\section{Material and Methods}

\subsection{Extraction of YTXs in Sediment}

$50 \mathrm{~g}$ sediment sample was weighted, and the cyst separation method was followed by K Matsuoka [22]. All the cysts were transferred to a $10 \mathrm{~mL}$ centrifuge tube, and centrifuged repeatedly, retained precipitation. $3 \mathrm{ml}$ methanol was added to the precipitation, by ultrasonication for $10 \mathrm{mins}$, the sample was centrifuged for $10 \mathrm{~min}$ under $3500 \mathrm{r} / \mathrm{min}$, and the supernatant was filtered through $0.22 \mu \mathrm{m}$ membrane for analysis by HPLC-MS/MS.

\subsection{Analysis Method for YTXs in Sea Water by HP20 Resin Adsorption}

Small bolting-silk bags $(50 \times 50 \mathrm{~mm})$ were sewed. Each bag contain ingredients $3 \mathrm{~g}$ HP20 resin and the bag was soaked $10 \mathrm{~min}$ in methanol, rinsed two times in distilled water, soaked them in pure water until used. The small bags handled were hung in seawater (generally hung on the shellfish frame), one month later, they were taken back to laboratory. The HP20 bags were washed with deionized water, then the resin was transferred into the centrifuge tube, got rid of water, $3 \mathrm{ml}$ methanol was added, extracted $10 \mathrm{~min}$ in ultrasound environment, centrifuged, filtered supernatant with $0.22 \mu \mathrm{m}$ membrane, and then detected YTXs by HPLC/MS/MS method.

\subsection{Analysis Method of YTXs in Plankton}

4L seawater sample was filtered with $0.45 \mu \mathrm{m}$ membrane and the filtered membrane was cut into pieces and put in centrifuge tube. Then $2 \mathrm{ml}$ methanol was added, the cells were broken using cell disrupter in ice water for $15 \mathrm{~min}$, centrifuged $15 \mathrm{~min}$ under $3500 \mathrm{r} / \mathrm{min}$, filtered supernatant using $0.22 \mu \mathrm{m}$ membrane, and then detected YTXs by HPLC-MS/MS method.

\subsection{The Detection of YTXs in Shellfish}

The method of detection YTXs in shellfish was followed according U-RL-MB [23].

\subsection{HPLC-MS/MS method for analysis YTXs and Standards Used}

HPLC-MS/MS: Dianex Ultimate 3000 LC and API 4000 mass spectrum, Waters X-Bridge $\mathrm{C}_{18} 3 \times 150 \mathrm{~mm}, 3.5 \mu \mathrm{m}$. The condition of HPLC-MS/MS referred to the method of EU-RL-MB [23]; YTX, homo-YTX, 45-OH-YTX, 45-OH-homoYTX and Carboxy-YTX structures can be detected.

The YTX and homo-YTX standards were purchased from National Research Council Canada. The quantitative of other structures were based on YTX standard. The reagents are analytically pure or chromatographically pure and the water was distilled water of Watsons.

\subsection{The Separation and Cultivation of $P$. reticulatum and YTXs Analysis}

P. reticulatum was separated from Dalian coast of the northern Yellow Sea in Feb 2014, and was Cultivated in $\mathrm{f} / 2$ medium without silicon and sterilized natural seawater, and under $15^{\circ} \mathrm{C}$ illumination intensity $3000 \mathrm{lux}$ and a proportion of $12 \mathrm{~h}: 12 \mathrm{~h}$ in darkness and light.

$5 \mathrm{ml}$ of $P$. reticulatum culture solution was filtered with $0.45 \mu \mathrm{m}$ membrane after counting; the filtered membrane was cut into pieces. Then $2 \mathrm{ml}$ methanol was added and mix it up, the cells were broken with sonicator in ice; centrifuged $10 \mathrm{~min}$ under $3500 \mathrm{~g} / \mathrm{min}$, filtered the supernatant with $0.22 \mu \mathrm{m}$ membrane and analysis YTXs by HPLC-MS/MS.

The above-mentioned filtrate, was treated using SPE pillar (phenomenex) which was activated using $1 \mathrm{ml}$ methanol, and SPE pillar was balanced by using $1 \mathrm{ml}$ of $30 \%$ methanol-water, then washed with $1 \mathrm{ml} 20 \%$ methanol-water, and then eluted using $1.2 \mathrm{ml} \quad 0.3 \%$ ammonia-methanol solution, which was analyzed by HPLC-MS/MS for YTXs.

\subsection{The Ecological Features of Toxic $P$. reticulatum}

$P$. reticulatum was cultured under different medium made by different nitrogen, phosphorus compound (as Tab. 1), and different salinity and temperature. The cells were counted with microscope and measured the size of cells each time,.5ml culture solution, was analyzed the YTXs in cells $(\geq 0.45 \mu \mathrm{m})$ and in seawater as above 2.6 showed.

\subsection{Feeding Trials with $P$. reticulatum}

A certain amount of shellfishes(Patinopecten yessoensis, mussel, Chlamys farreri) were put in the tank, then certain volume of filtered natural seawater was added, input air with air pump continuously, fed them with bait algae or toxic $P$. reticulatum, changed the seawater and picked out the died shellfish every day. 5 shellfishes were randomly selected, to measure the size and peel the soft tissue to analyze YTXs by HPLC-MS/MS(see 2.4). 
Table 1. The Culture Medium for P. reticulatum with Different $\mathrm{N}$ and P Source

\begin{tabular}{|c|c|c|c|c|c|}
\hline & \multicolumn{5}{|c|}{ Nitrogen Source $\left(8.82 \times 10^{-4} \mathrm{~mol} / \mathrm{L}\right)$} \\
\hline code & control & A & B & $\mathrm{C}$ & $\mathrm{D}$ \\
\hline $\begin{array}{l}\text { Molecular } \\
\text { Formula }\end{array}$ & $\mathrm{NaNO}_{3}$ & $\mathrm{NH}_{4} \mathrm{Cl}$ & $\mathrm{NH}_{4} \mathrm{NO}_{3}$ & $\mathrm{C}\left(\mathrm{NH}_{2}\right)_{2} \mathrm{CO}$ & No Nitrogen \\
\hline \multirow[t]{2}{*}{ Name } & Sodium Nitrate & Ammonium Chloride & $\begin{array}{l}\text { Ammonium } \\
\text { Nitrate }\end{array}$ & Urea & \\
\hline & \multicolumn{5}{|c|}{ Phosphorus Source $\left(3.62 \times 10^{-5} \mathrm{~mol} / \mathrm{L}\right)$} \\
\hline code & control & $\mathrm{E}$ & $\mathrm{F}$ & G & $\mathrm{H}$ \\
\hline $\begin{array}{l}\text { Molecular } \\
\text { Formula }\end{array}$ & $\mathrm{NaH}_{2} \mathrm{PO}_{4} \cdot \mathrm{H}_{2} \mathrm{O}$ & $\mathrm{C}_{3} \mathrm{H}_{16} \mathrm{~N}_{5} \mathrm{O}_{13} \mathrm{P}_{3}$ & $\mathrm{C}_{3} \mathrm{H}_{7} \mathrm{Na}_{2} \mathrm{O}_{6} \mathrm{P}$ & $\mathrm{Ca}\left(\mathrm{H}_{2} \mathrm{PO}_{4}\right)_{2} \cdot \mathrm{H}_{2} \mathrm{O}$ & $\begin{array}{c}\text { No } \\
\text { Phosphorus }\end{array}$ \\
\hline Name & $\begin{array}{c}\text { Sodium Dihydrogen } \\
\text { Phosphate }\end{array}$ & $\begin{array}{l}\text { ATP: Adenosine } \\
\text { Triphosphate }\end{array}$ & $\begin{array}{l}\text { Adenosine } \\
\text { Phosphate }\end{array}$ & $\begin{array}{c}\text { Triple } \\
\text { Superphosphate }\end{array}$ & \\
\hline
\end{tabular}

\section{Results}

\subsection{The Distribution of YTXs in the Northern Yellow Sea}

We selected 8 stations in the northern Yellow Sea coast where HAB happens frequently and have record of YTXs(Fig.1), and seawater, plankton, sediments and bivalve mollusk was collected, the distribution and regular pattern of YTXs was researched.
$122.0^{\circ}$
$123.0^{\circ}$

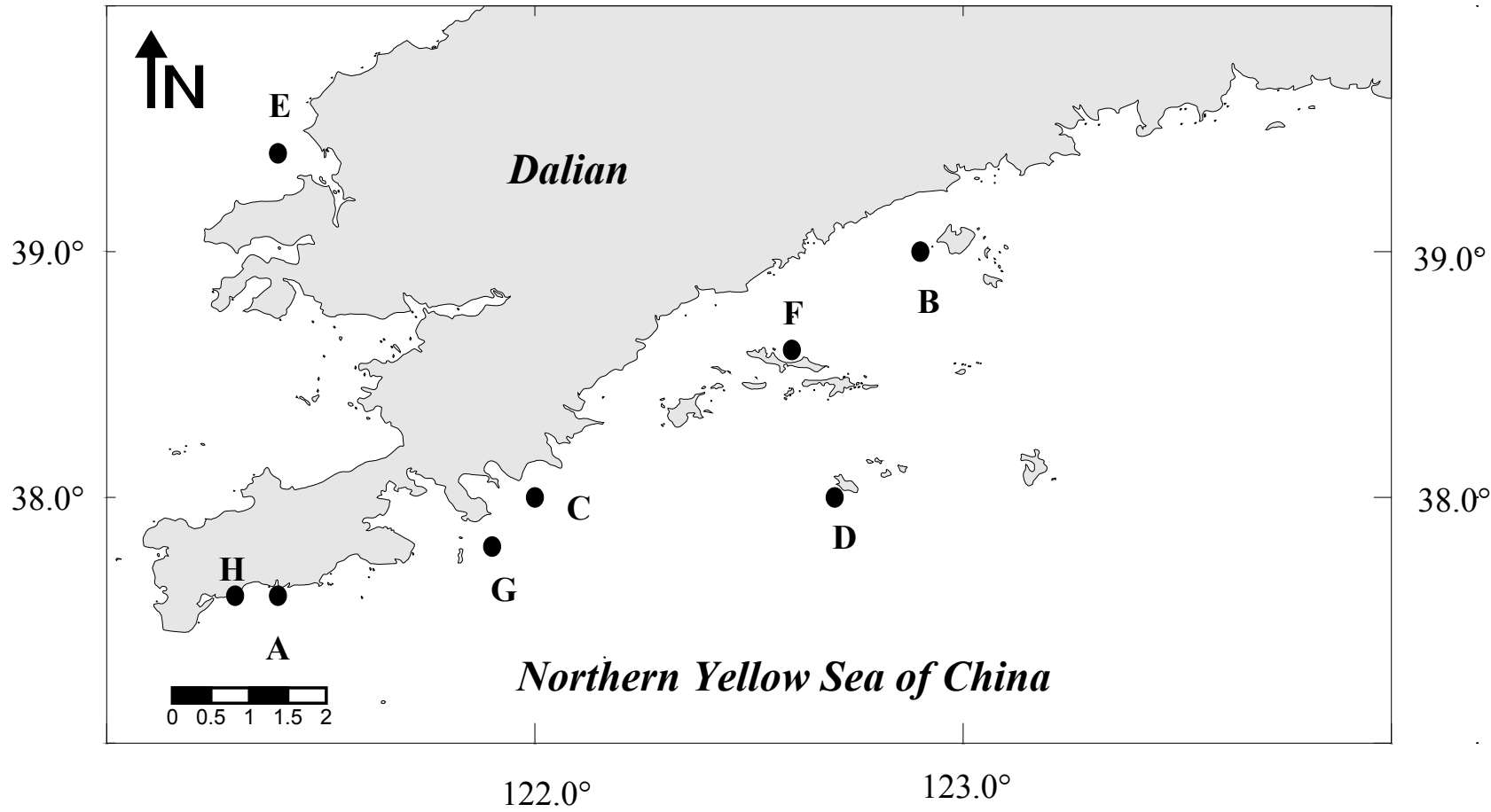

Figure 1. Sampling stations map

\subsubsection{YTXs in Cysts of Sediment}

There were lower YTXs in sediment cysts. From Jan to Mar, the content of YTXs in sediment was higher than other months. While in E station it reached to the peak in October; in other months, most of time, it was under detection limit or not detected (see Fig. 2a). In 2013, the maximum of YTX in cyst appeared at B site in Mar and at E site in Oct; there were two peaks in E this year, the YTX decreased followed in Feb, Mar, Apr and May. 

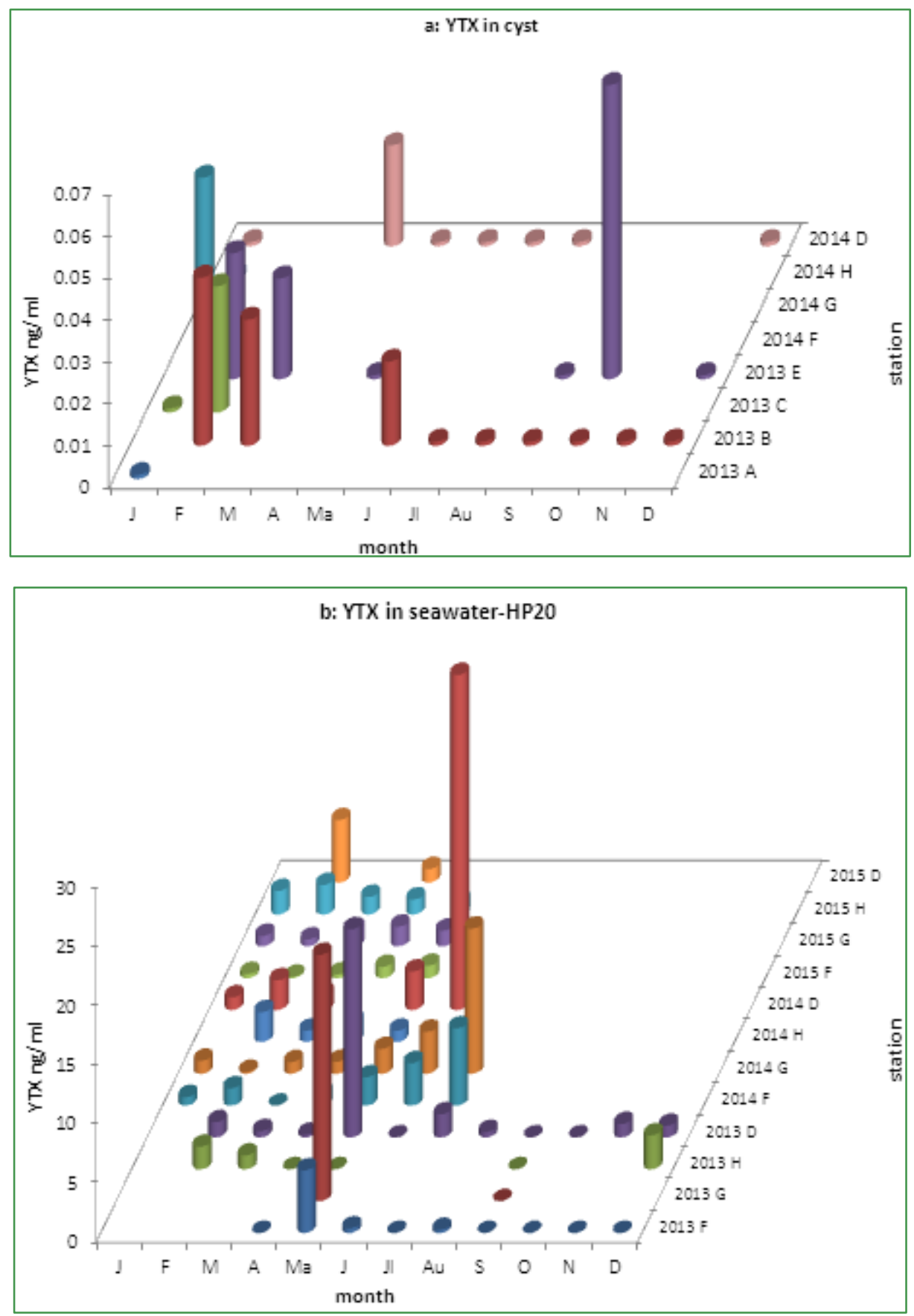


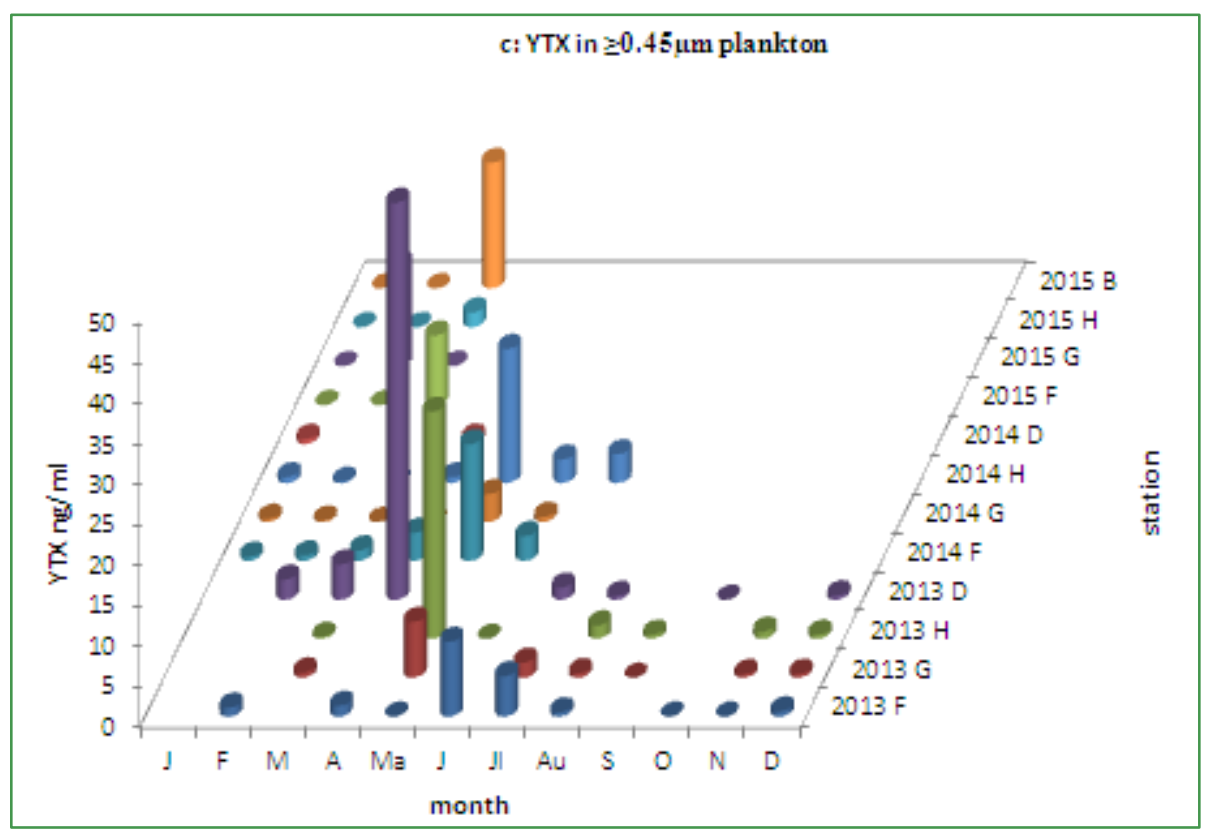

Figure 2. Comparison of YTXs in cyst (a), in seawater (b) and in plankton (c) in different stations from the northern Yellow Sea of China

\subsubsection{The Distribution of YTXs in Seawater of the Northern Yellow Sea}

The higher value of YTXs in seawater appeared in May, June and July. There was the highest content in D site at Jun 2014(Fig. 2b). The YTXs varied from different sites and particular years, but the change trend is basically same with the time when YTXs reached to the highest in phytoplankton.

\subsubsection{The YTXs in Planktons}

\subsubsection{The Composition of Phytoplanktons}

From Feb to April 2013, the surface seawater sample from D site were collected and observed under microscope. There were six species of phytoplankton: Ditylum spp, Melosira spp, Coscinodiscus spp, Thalassiosira spp, Protoperidinium. spp and the dinoflagellate with highest density which was later identified as $P$. reticulatum according to the morphology and genetics. While YTXs was both detected in planktons and seawater (detailed in another essay), this was also the first time to find the moving cells of $P$. reticulatum in Chinese coast waters.

\subsubsection{The YTX in Plankton from the Northern Yellow Sea of China}

The level of YTXs in plankton reached to the peak in April and May, while it was flowed in June and July. In other months, it was under detection limit or not detected; the maximum YTX appeared in D with $24.6 \mathrm{ng} / \mathrm{L}$ in planktons $(\geq 0.45 \mu \mathrm{m}$ PM) (Fig. 2c); by comparison, it was showed that the peak time of YTXs in planktons appeared a little later than that in the sediment cyst.

\subsubsection{The Distribution of YTX in Bivalve Mollusk from the Northern Yellow Sea}



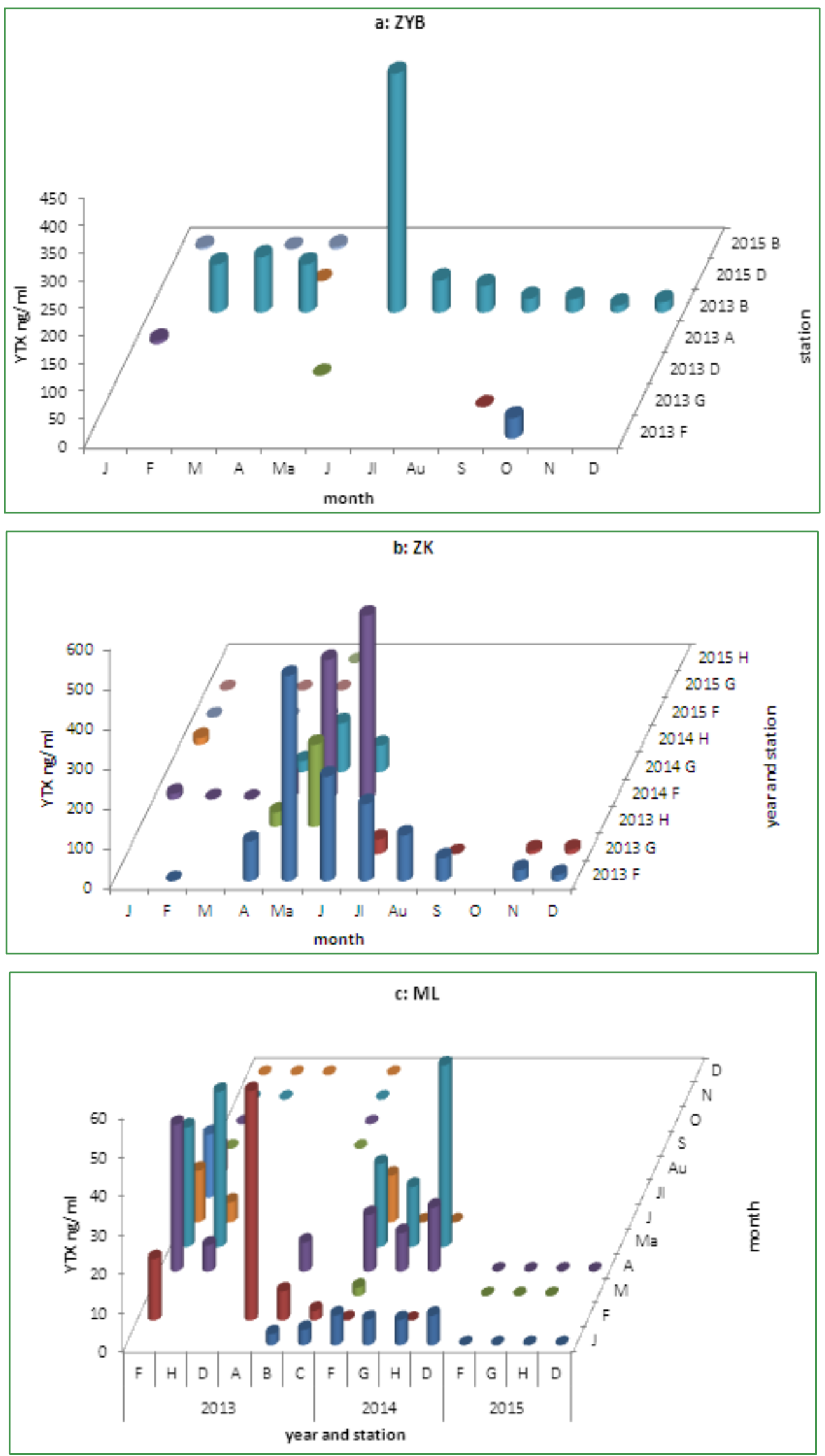

Figure 3. The changed YTX in the mussel (Mytilus galloprovincialis)(a), in Chlamys farreri (b) and in oyster (c) from the northern Yellow Sea 
The highest of YTXs was $3.9 \mu \mathrm{g} / \mathrm{g}$ in Mytilus galloprovincialis from B station near Dalian coast in June 2013 which has exceeded safety threshold of $3.75 \mathrm{mg} / \mathrm{kg}$, but it was lower than the safety limitation in other months; the YTX in Feb to Apr was higher than that in autumn (Sep to Nov.)(Fig. 3a). For Chlamys farreri from Dalian coast, the highest level of YTX was $4.9 \mu \mathrm{g} / \mathrm{g}$ both in May 2013 and June 2014, and YTX from Apr to Aug had all higher than the safety threshold; the YTX was gradually reducing from May, June, July, August and September while it began increase in November, December and January again; the YTX varied in the different year, the YTX in Chlamys farreri in 2015 was notably lower than that in 2013 and 2014(Fig.3b).

The YTXs in oyster from the Yellow Sea coast was overall quite low; the YTXs in oyster from H site near Dalian coast was a little higher than that in other stations and it was the highest in May; in A site near Lvshun coast, in Feb YTX was the highest; the YTX in oyster in 2015 was lower than that in 2014 and 2013, the YTX was all far low than the safety threshold while the highest value of YTX was $0.5 \mathrm{mg} / \mathrm{kg}$ in Feb 2013; near Dalian coast, the YTX from Apr to July was a little higher than that in Feb and Mar, and it was below the detection limit from Oct to Dec(Fig.3c).
The YTXs varied according to the species of bivalve mollusk. The oyster had the lowest YTXs while it was far higher in M. galloprovincialis (ZYB)and C. farreri (ZK) than that in the oyster(ML), at the same time, the level of YTXs in C. farreri was a little higher than that in $M$. galloprovincialis for the most stations; the peak time of the highest YTXs all appeared in May for all shellfishes, and as time went, the level declined till Sep, and it reached to the lowest in Oct, Nov and Dec(Fig.4).

\subsubsection{The Distribution of the Three Dinoflagellates Which Could Produce YTXs in the Northern Yellow Sea}

$P$. reticulatum, $L$. polyedrum and $G$. spinifera have all been found in the northern Yellow Sea of China (Fig. 5). $P$. reticulatum was the most widely distributed and also had the highest density, G. spinifera followed, only in Apr 2013 L. polyedrum had been found in the $\mathrm{F}$ site with a density of 360 cells $/ \mathrm{ml}$; the highest abundance of $P$. reticulatum all appeared in the Apr and May (Fig.6); both P. reticulatum and G. spinifera reached the highest abundance in D station with 47550 cells $/ \mathrm{ml}$ and 7910 cells $/ \mathrm{ml}$ in Apr 2013.

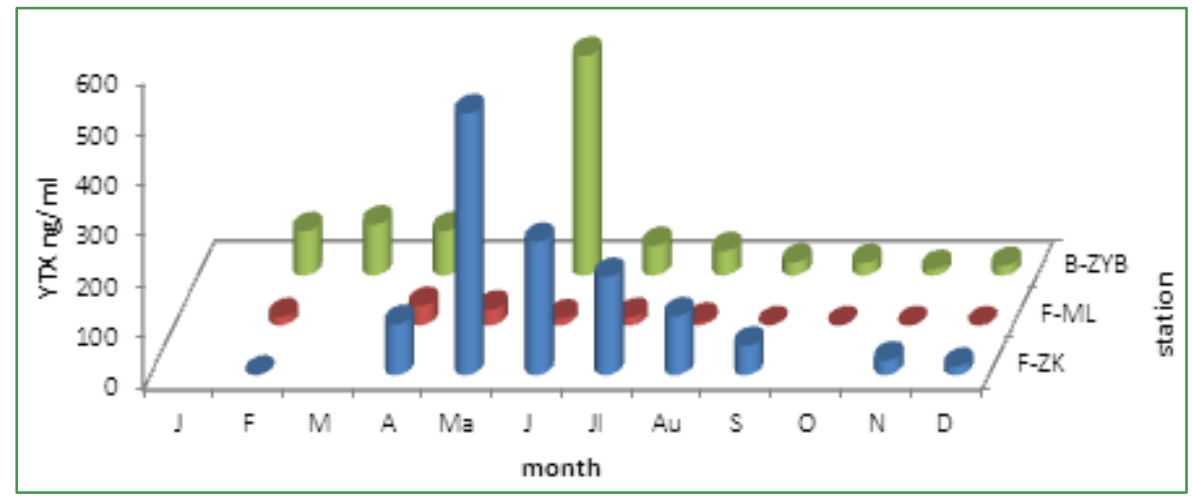

Figure 4. The comparison YTX in different bivalve from the northern Yellow Sea

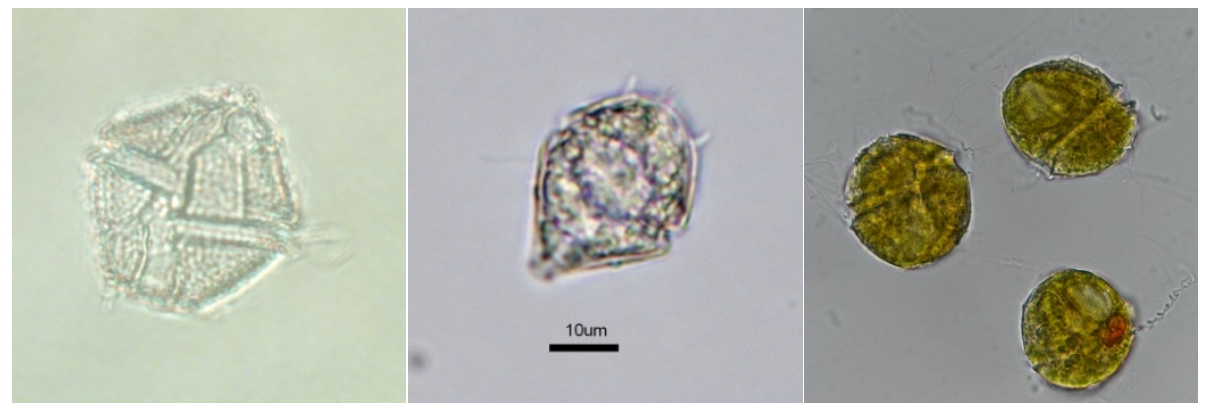

Figure 5. Lingulodinium polyedrum(left), Gonyaulax spinifera (middle), Protoceratium reticulatum (right)from the northern Yellow sea 


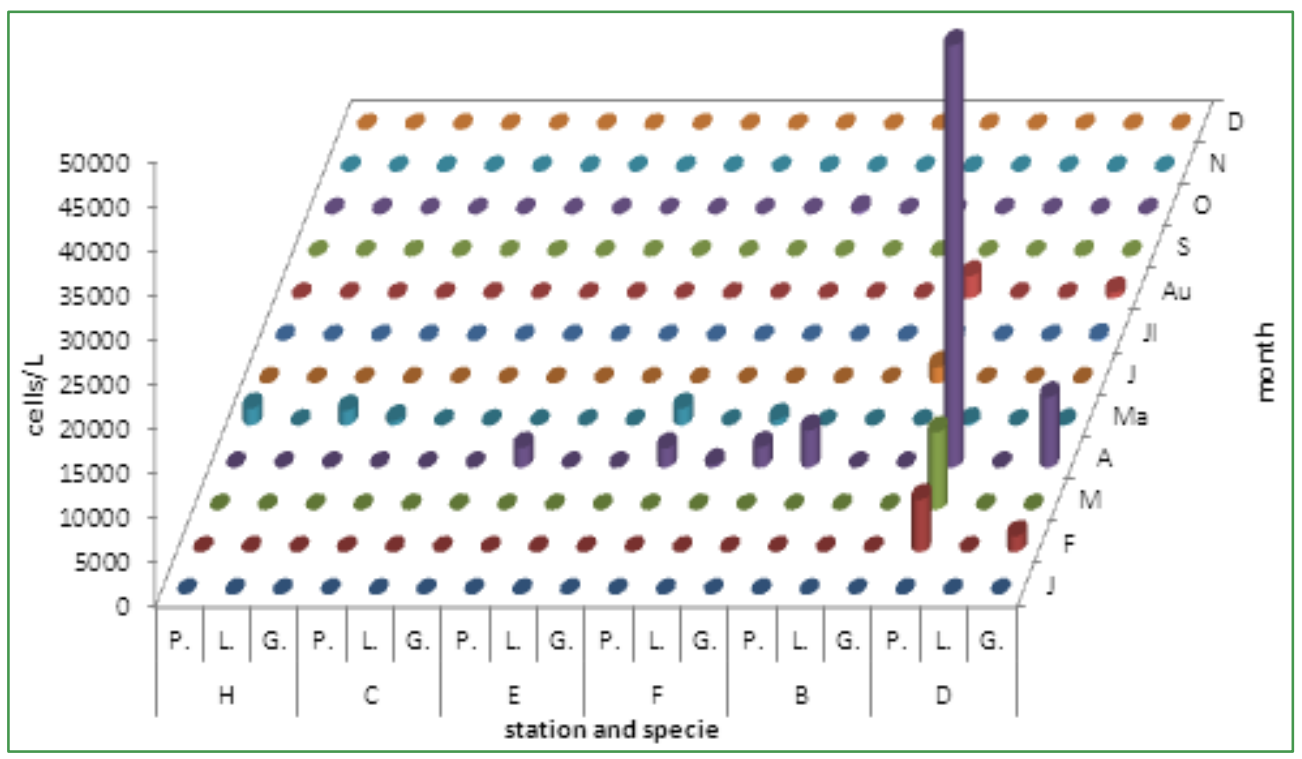

Figure 6. The distribution of three species of dinoflagellates in 2013 (P.: P. reticulatum; L.: L. polyedrum; G.: G. spinifera)

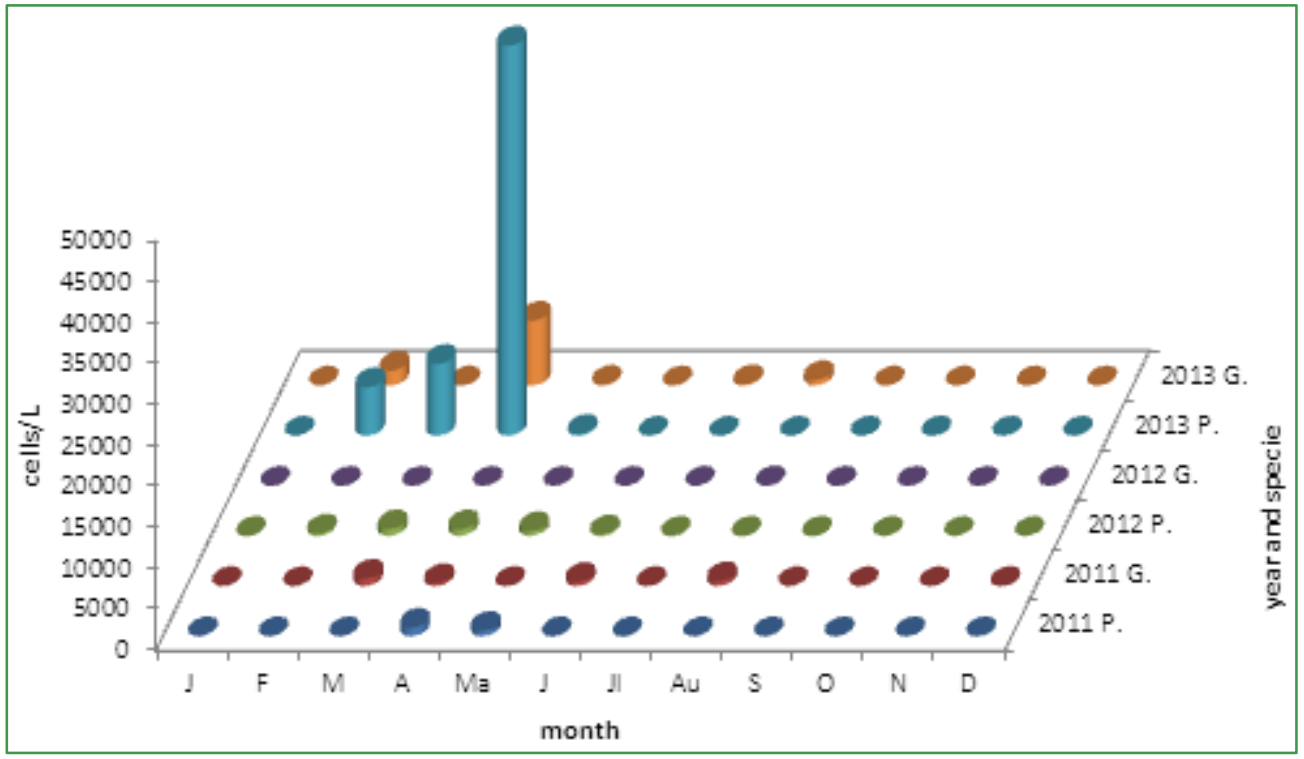

Figure 7. The comparison of abundance of three species dinoflagellates in D site from 2011 to 2013 (L. polyedrum had not been found in three years.)

The abundance of the three dinoflagellates which could produce YTXs toxin was different in the same site in different years; both frequency and abundance of $P$. reticulatetum was all far higher than that of $G$. spinifera. The peak abundance was all in Apr every year; G. spinifera had the highest abundance in Mar 2011 and 2012, while it reached to the peak in Apr 2013; and L. polyedrum had not been found in three years of 2011 to 2013(Fig.7).

\subsection{The Ecological Features of $P$. reticulatum}

3.2.1. The Growth and Production YTXs of the $P$. reticulatum in Different Salinity of 10\%, 20\%, 30\%o.

The density of $P$. reticulatum rose slightly along time, it reached the most density at 95days with about 35000 cells $/ \mathrm{ml}$, and then gradually reduced till death. The most suitable salinity for the growth of $P$. reticulatum was $20 \%$ salinity, and followed was $30 \%$ at the initial stage $(<35 \mathrm{~d})$, but it was $10 \%$ at the last stage( $>35 \mathrm{~d})$ (Fig.8a). 

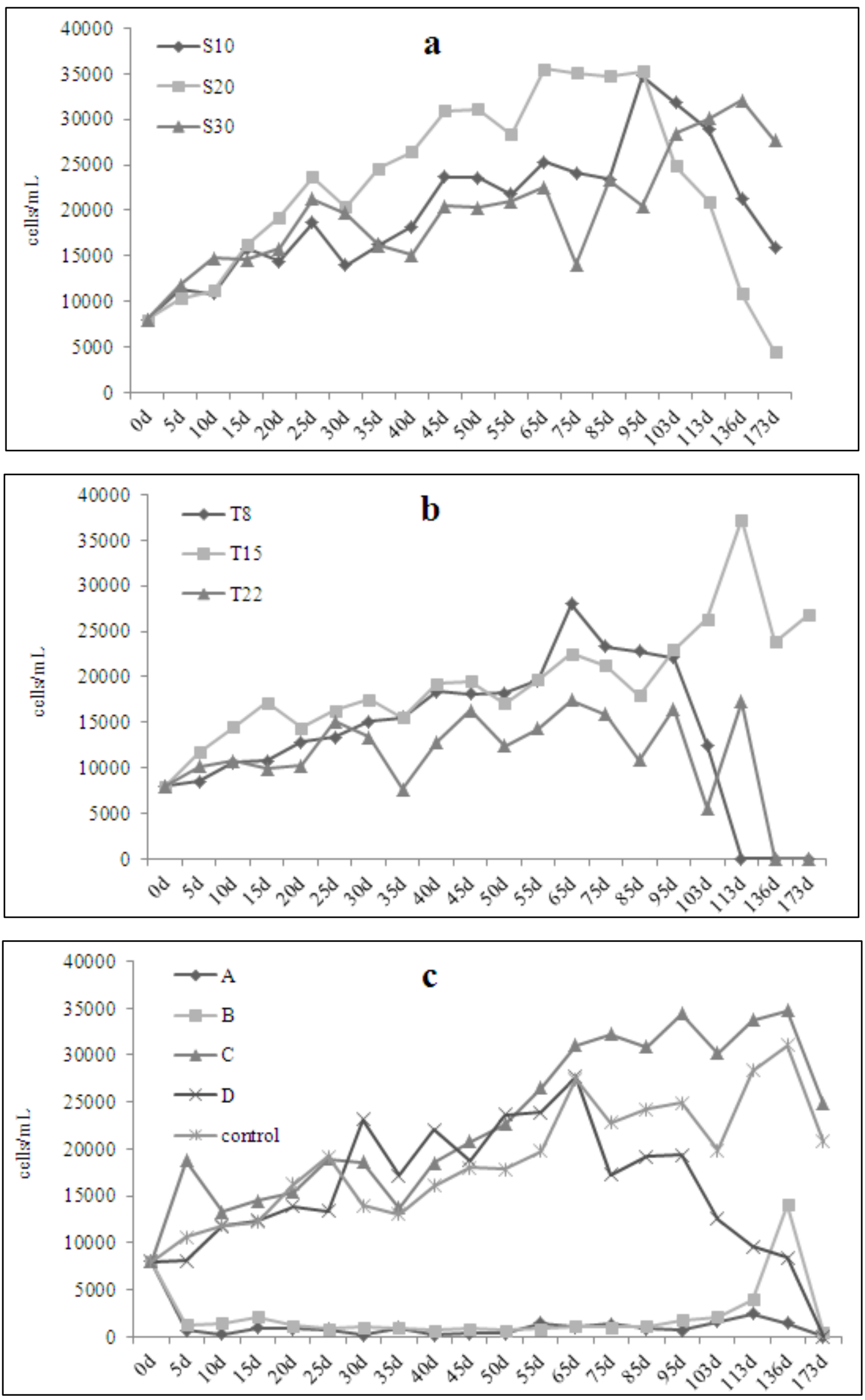


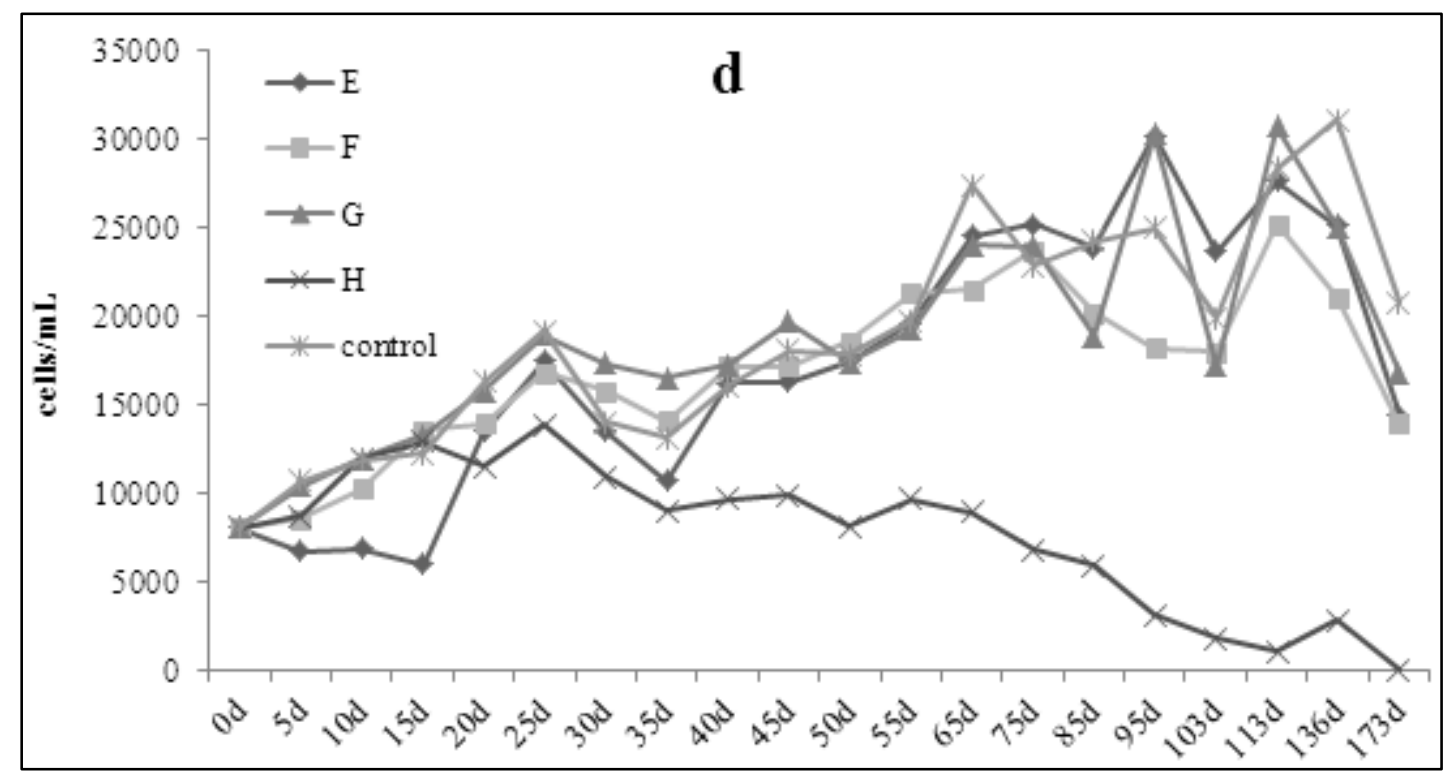

Figure 8. The density change of $P$. reticulatum: a in different salinity; b in different temperature; $\mathrm{c}$ in different nitrogen source $\left(\mathbf{A}: \mathrm{NH}_{4} \mathrm{Cl} ; \mathbf{B}: \mathrm{NH}_{4} \mathrm{NO}_{3}\right.$; C: $\left(\mathrm{NH}_{2}\right)_{2} \mathrm{CO}$; D: no nitrogen; control: $\left.\mathrm{NaNO}_{3}\right)$; $\mathrm{d}$ in different phosphorus sources(E: $\operatorname{ATP}\left(\mathrm{C}_{10} \mathrm{H}_{16} \mathrm{~N}_{5} \mathrm{O}_{13} \mathrm{P}_{3}\right.$, adenosine triphosphate); F: $\mathrm{C}_{3} \mathrm{H}_{7} \mathrm{Na}_{2} \mathrm{O}_{10} \mathrm{P}$, adenosine phosphate; $\mathrm{G}$ : $\mathrm{Ca}\left(\mathrm{H}_{2} \mathrm{PO}_{4}\right)_{2} \cdot \mathrm{H}_{2} \mathrm{O}$, triple superphosphate; $\mathrm{H}$ : without phosphorus sources; control: $\mathrm{NaH}_{2} \mathrm{PO}_{4} \cdot \mathrm{H}_{2} \mathrm{O}$, sodium dihydrogen phosphate).

The cells of $P$. reticulatum would not becoming bigger with time till 45 days, from the $45 \mathrm{~d}$, the cell diameter increased rapidly from $24.5 \mu \mathrm{m}$ to $45 \mu \mathrm{m}$ of 55 days, then it decreased quickly to $27 \mu \mathrm{m}$ at 75 days, and then continued to shrink to $26.5 \mu \mathrm{m}$ (Fig.9a). The diameter of $P$. reticulatum almost does not change with different salinity.

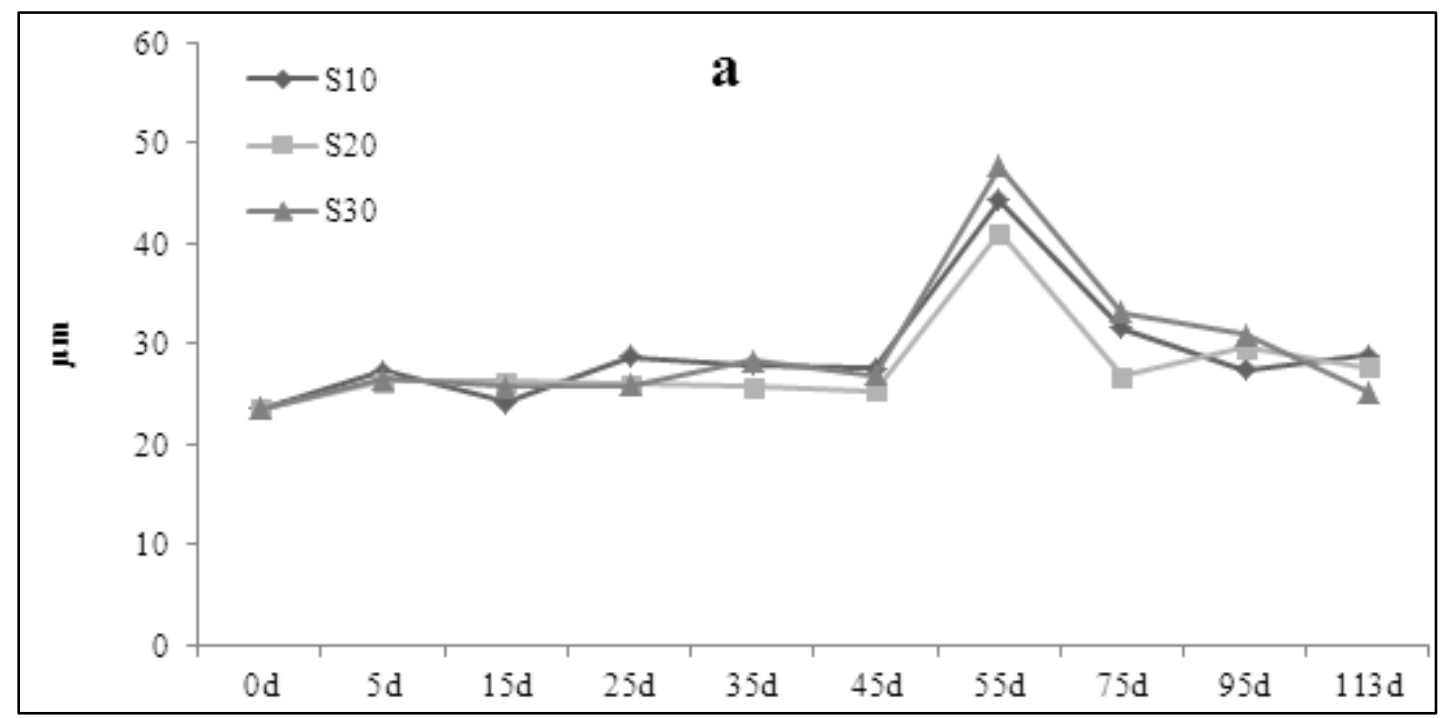



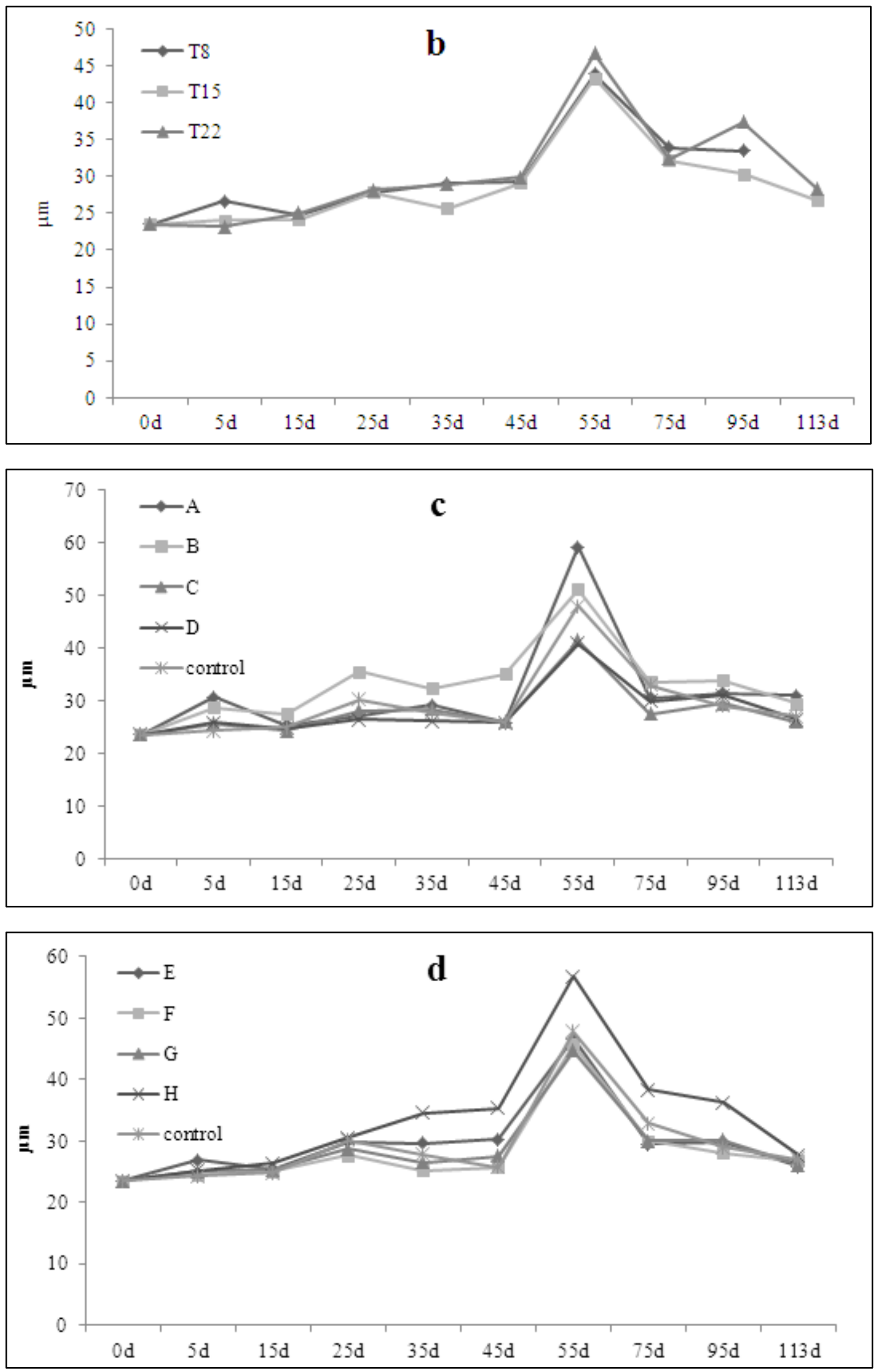

Figure 9. The cells size change of $P$. reticulatum: $\mathrm{a}$ in different salinity; $\mathrm{b}$ in different temperature; $\mathrm{c}$ in different nitrogen source; $\mathrm{d}$ in different phosphorus sources. 
The P. reticulatum produced YTXs which mainly contains YTX congener and a little homo-YTX congener; most YTXs toxin existed inside the cells and only a little of YTXs existed outside the cells, in seawater; the maximum ratio of extracellular and intracellular YTXs was about 21 times; at about 113d, YTXs was produced by $P$. reticulatum under all three salinity all reached the highest amount with a maximum of $6.2 \mu \mathrm{g} / \mathrm{ml}$ (sum of YTXs inside and outside the cells) special under $30 \%$; the amount of YTXs which was produced by the P. reticulatum under 30\%o was higher than that under $20 \%$ and $10 \%$ (Fig.10a).The amount of YTXs for a single cell also showed a decreasing trend from $30 \%$, to $20 \%$ and then to 10\%o(Fig.11a). The most suitable salinity for P. reticulatum's growing was under 20\%, and while the greatest YTXs produced was under $30 \%$ salinity.

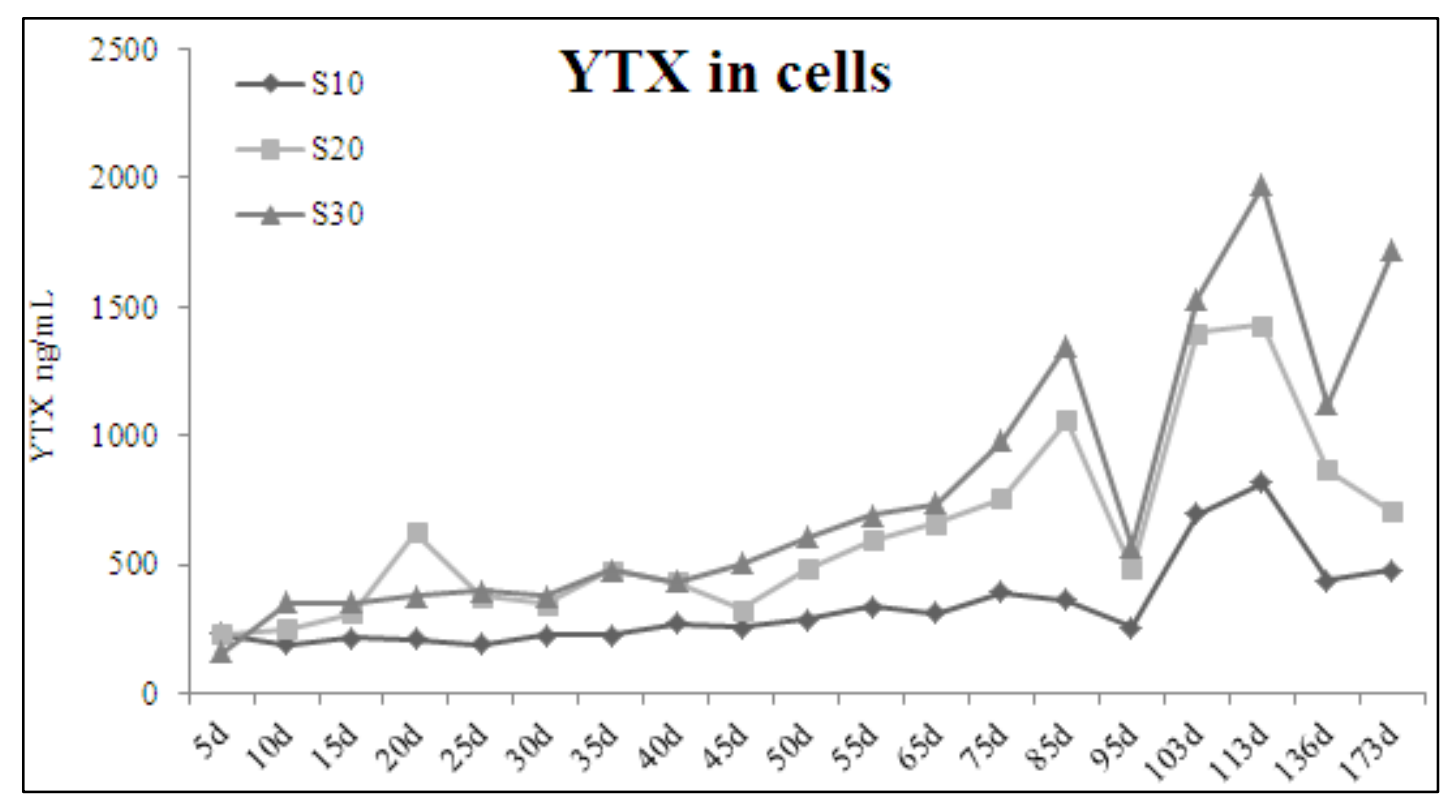

a

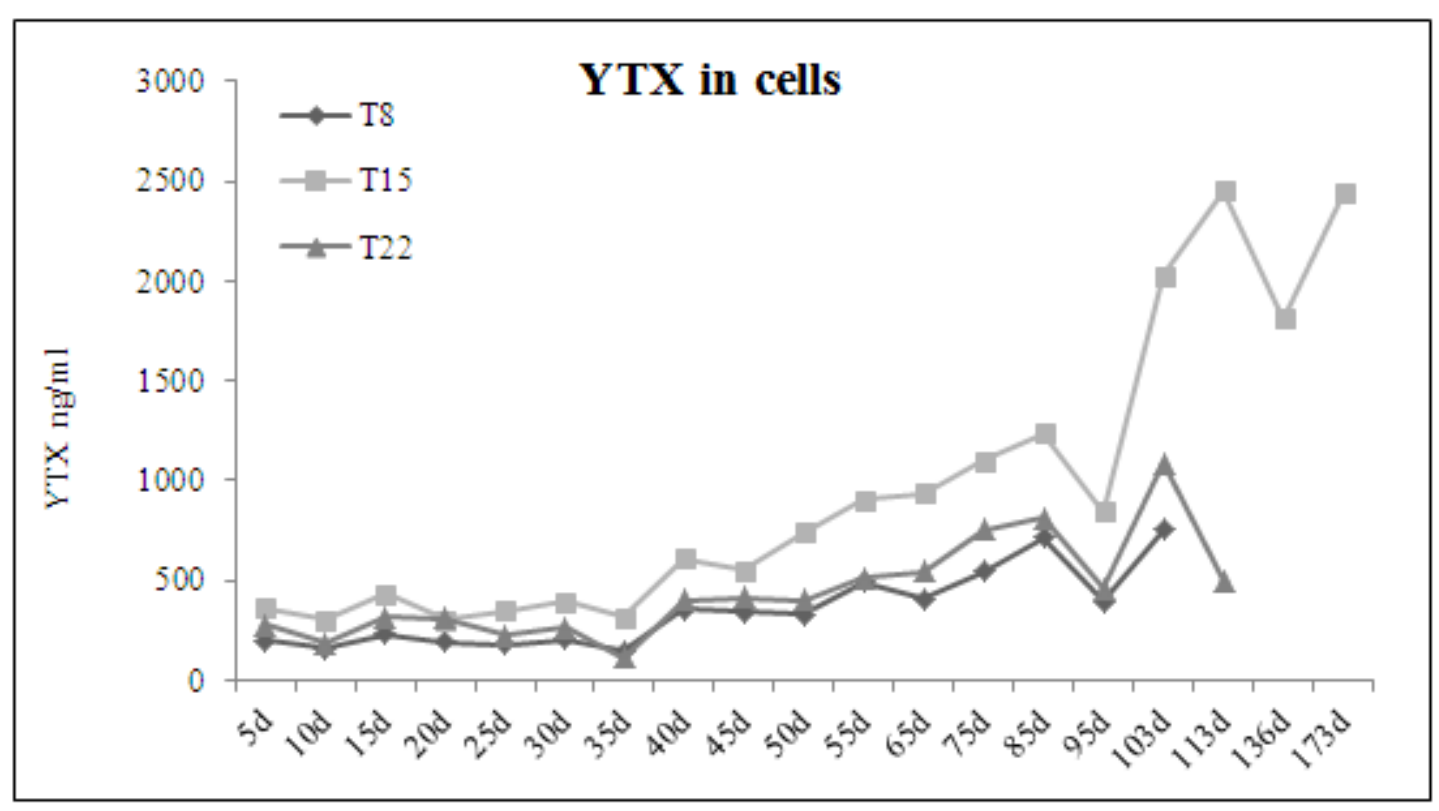




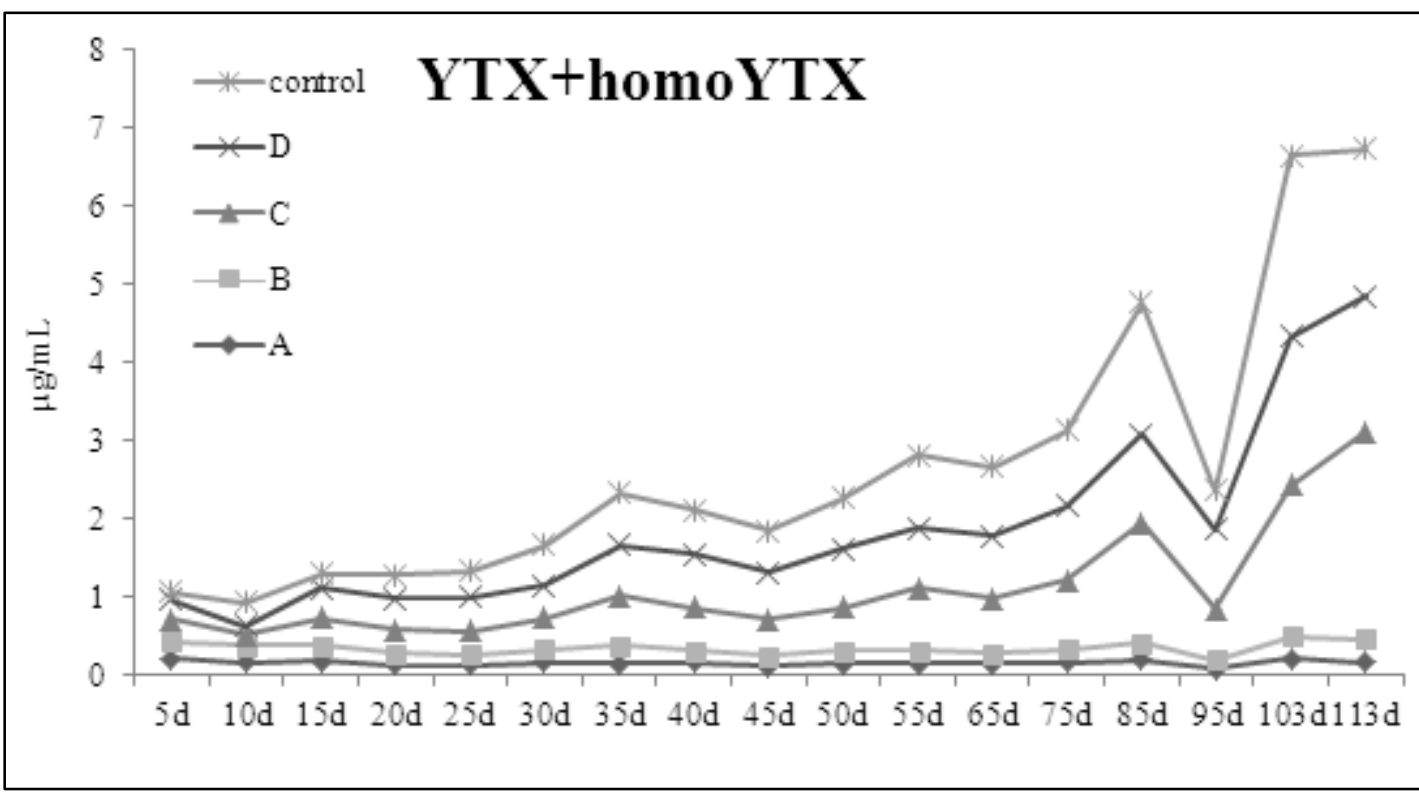

c

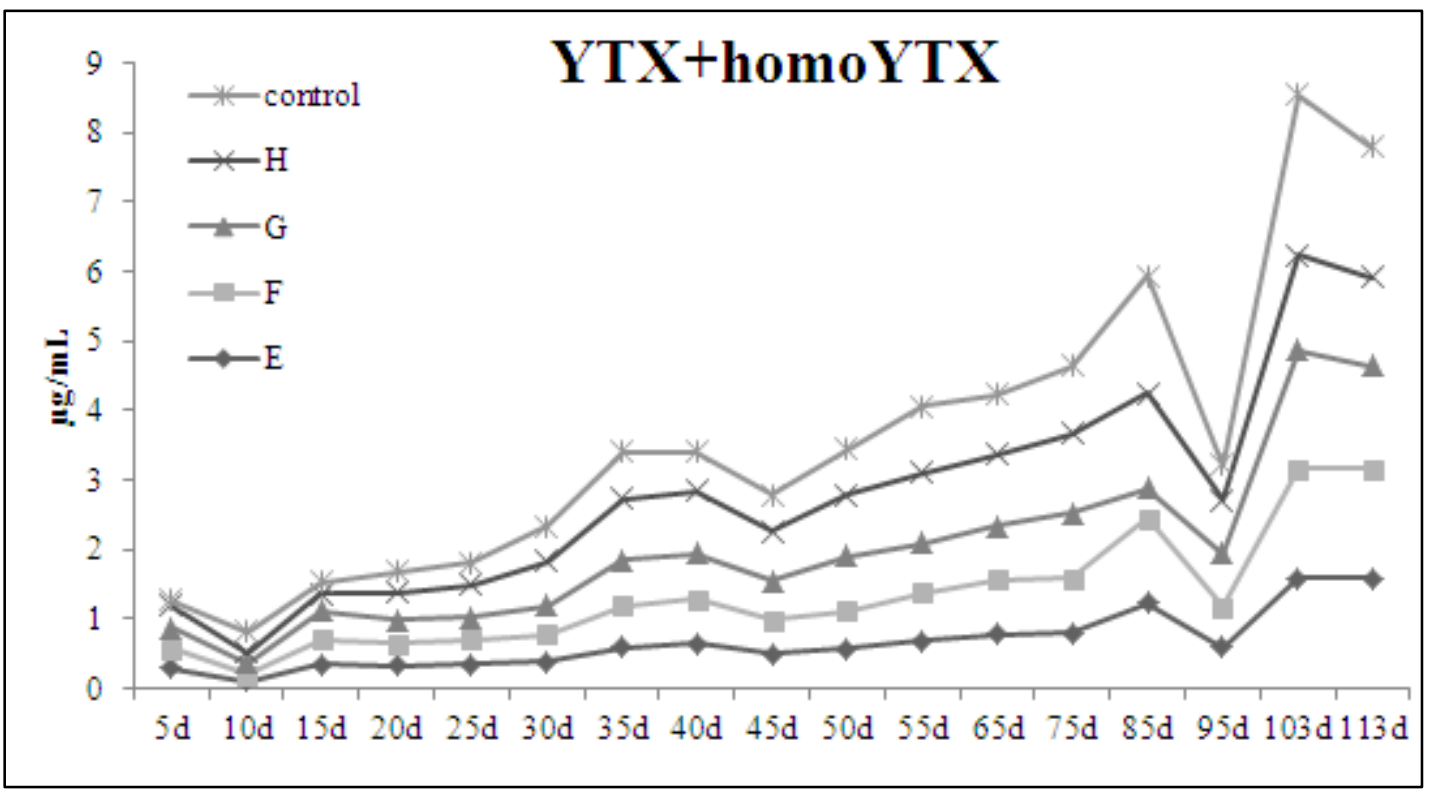

d

Figure 10. The YTXs produced by P. reticulatum inside cells under different salinity (a), different temperature (b), different nitrogen source (c) and different phosphorus sources. (d) 


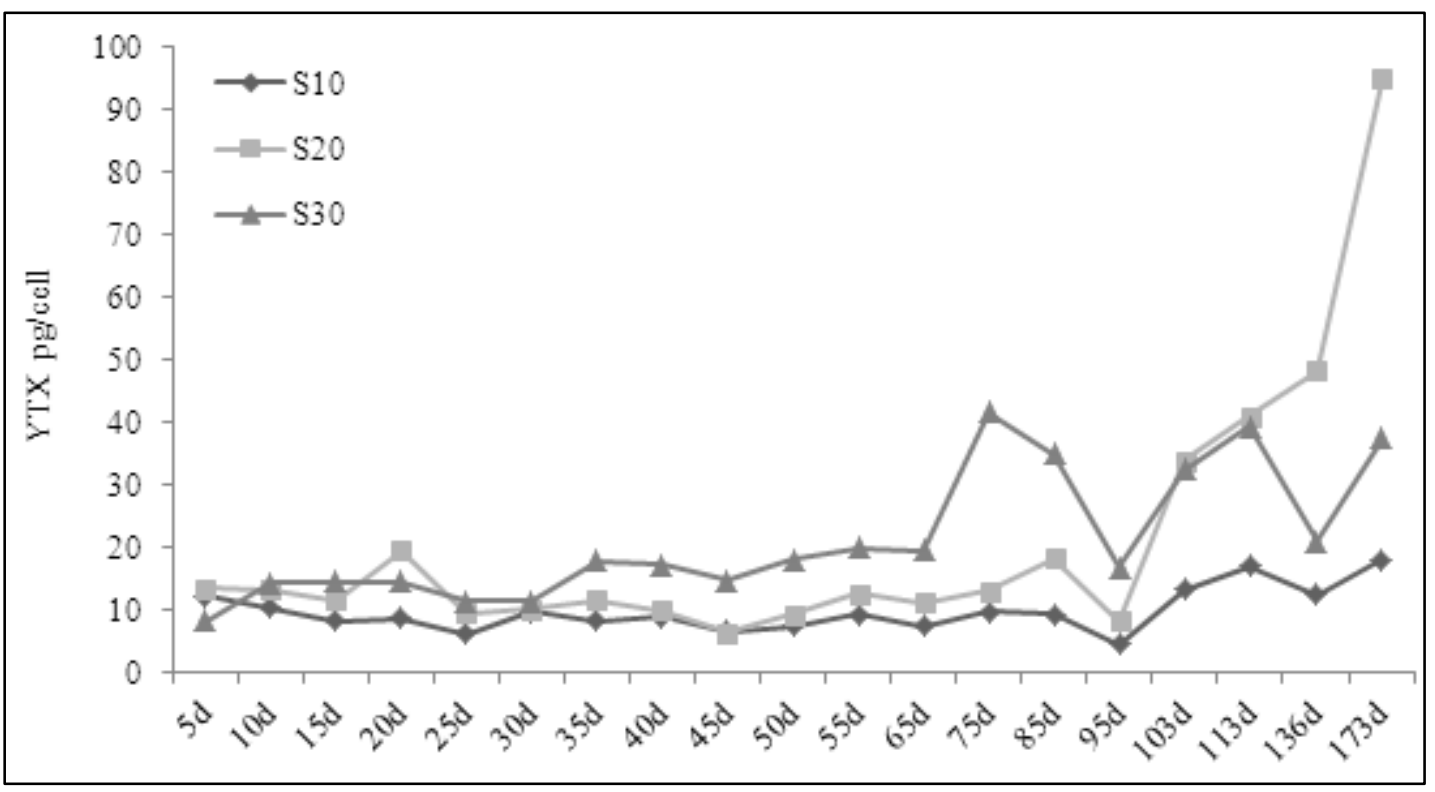

a

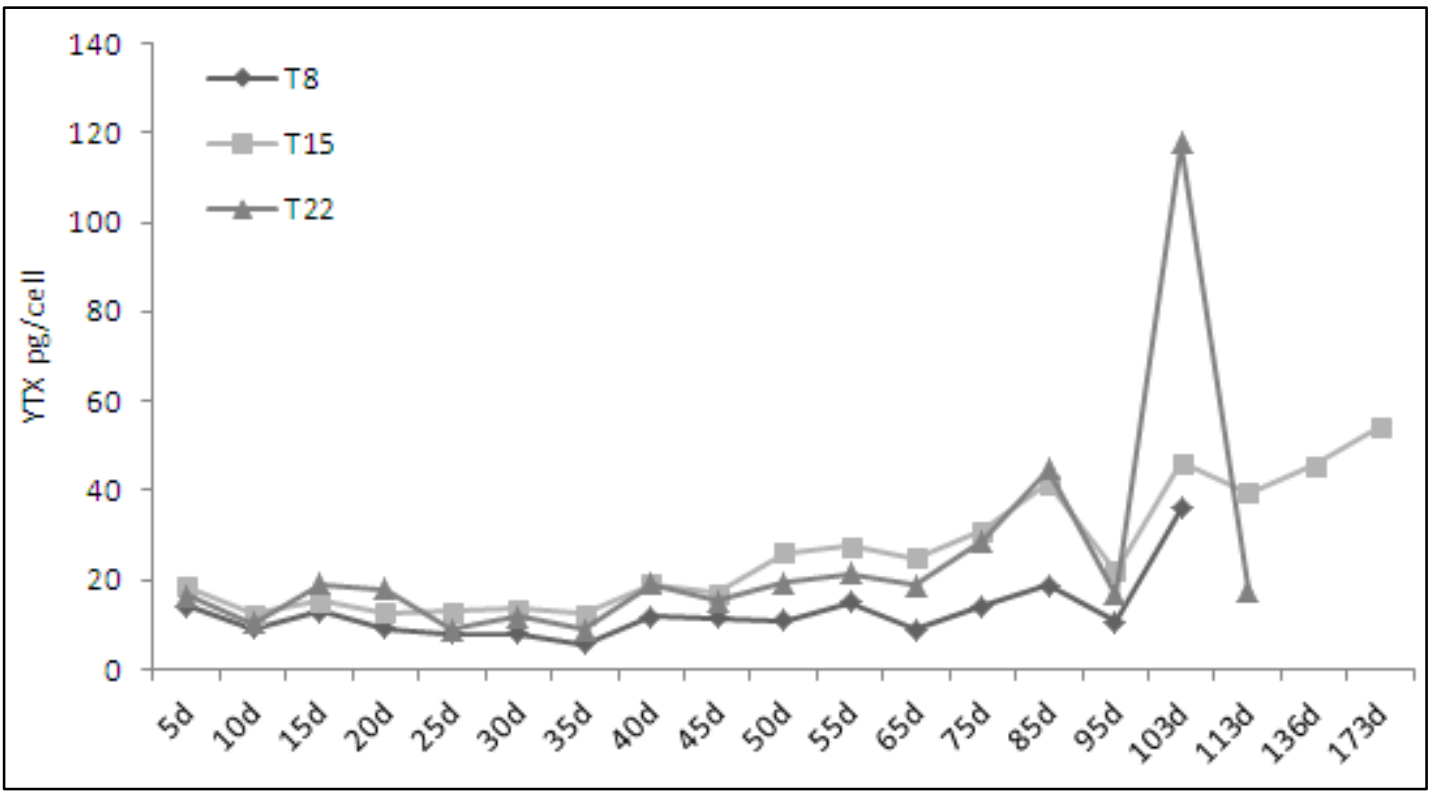




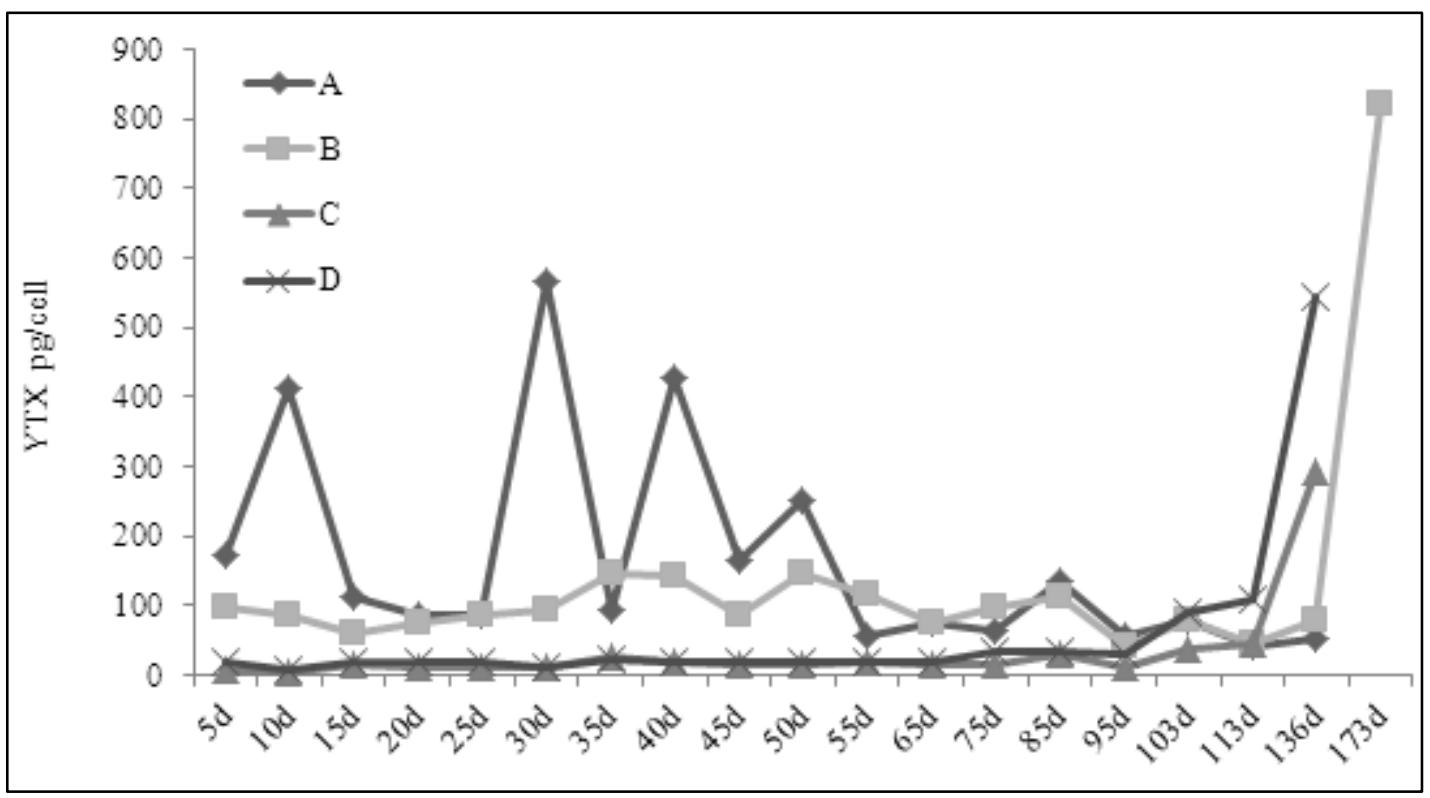

C

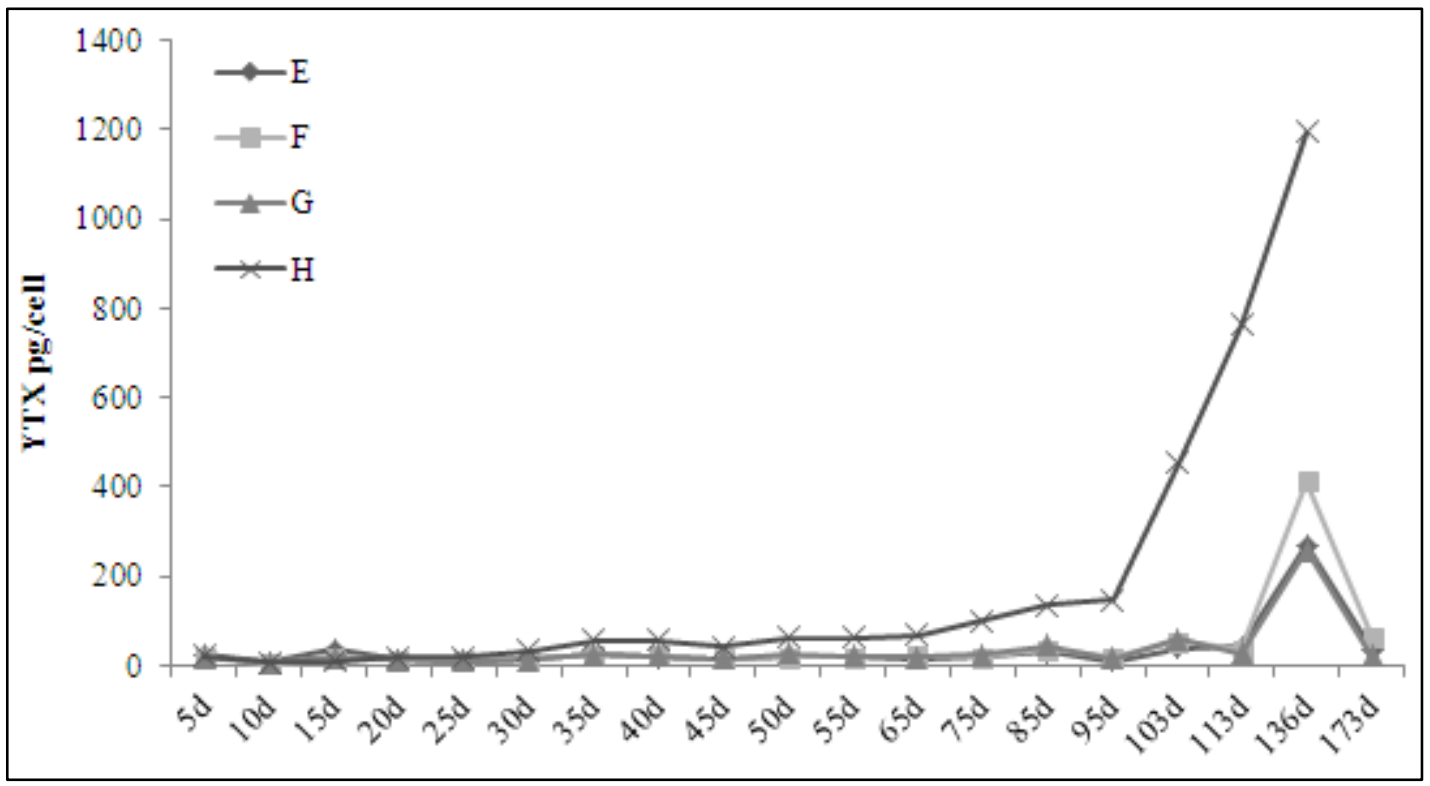

d

Figure 11. The YTX produced by P. reticulatum in single cell under different salinity (a), different temperature (b), different nitrogen source (c) and different phosphorus sources (d).

\subsubsection{The growth and production YTXs of the P. reticulatum} under different temperature of $8^{\circ} \mathrm{C}, 15^{\circ} \mathrm{C}$ and $22^{\circ} \mathrm{C}$.

The time of reaching the maximum density of $P$. reticulatum which be cultured under different temperatures was different. The suitable temperature for $P$. reticulatum's growth was under $15^{\circ} \mathrm{C}$, and under $8^{\circ} \mathrm{C}$ followed; the time of cells declining under $15^{\circ} \mathrm{C}$ was later than that under $8^{\circ} \mathrm{C}$, the density of cells in $15^{\circ} \mathrm{C}$ increased till $113 \mathrm{~d}$ with 37300 cells $/ \mathrm{ml}$, then it started declining, there was still the density of $27000 \mathrm{cells} / \mathrm{ml}$ without much decline at $173 \mathrm{~d}$. The density of cells in $22^{\circ} \mathrm{C}$ was lower than that in $8^{\circ} \mathrm{C}$ and $15^{\circ} \mathrm{C}$ (Fig. $8 \mathrm{~b}$ ). This clonal strain of $P$. reticulatum coming from the northern
Yellow Sea of China is specie of low temperature preferences. The cells size of $P$. reticulatum almost had no relationship with the temperature, but only depends the growth time. Three experiments group all reached the maximum diameter at the same time of 55 days (Fig. 9b).

The results showed that YTXs profiles of $P$. reticulatum were major YTX compounds and a little homo-YTX, and the most YTXs toxin existed inside the cells and only a little of it was in seawater under different temperature, the maximum ratio of extracellular and intracellular YTXs was about 16 times; at about $136 \mathrm{~d}$, YTXs produced by $P$. reticulatum under all three temperature all reached the highest amount 
with a maximum of $1.5 \mu \mathrm{g} / \mathrm{ml}$ (sum of YTXs inside and outside the cells) special under $15^{\circ} \mathrm{C}$; the amount of YTXs which was produced by the $P$. reticulatum under $15^{\circ} \mathrm{C}$ was higher than that under $22^{\circ} \mathrm{C}$, and the smallest YTXs under $8^{\circ} \mathrm{C}$ (Fig.10b, Fig12, Fig13). The amount of YTXs for a single cell also showed a decreasing trend from $15^{\circ} \mathrm{C}$ to $22^{\circ} \mathrm{C}$, and then $8^{\circ} \mathrm{C}$ (Fig. 11b). The most suitable temperature was all under $15^{\circ} \mathrm{C}$ both for the growth and production YTXs of Protoceratium reticulatum.

\subsubsection{The Growth and Production YTXs of the $P$.} reticulatum under different Nitrogen Sources
The most suitable nitrogen source for $P$. reticulatum's growth was urea $\left(\left(\mathrm{NH}_{2}\right)_{2} \mathrm{CO}\right)$; the density of $P$. reticulatum rose slowly. It has the most amounts at 95days with 35000 cells $/ \mathrm{ml}$ and then gradually began to decline. $\mathrm{NH}_{4} \mathrm{Cl}$ and $\mathrm{NH}_{4} \mathrm{NO}_{3}$ could not promote the growth of cells, but made it to begin to die, and $\mathrm{NH}_{4} \mathrm{Cl}$ had the stronger inhibitory affection on growth of cells than $\mathrm{NH}_{4} \mathrm{NO}_{3}$; without nitrogen source, $P$. reticulatum had the highest density at 65 days with $28000 \mathrm{cells} / \mathrm{ml}$ and then started to decline (Fig. 8c).The cell size of $P$. reticulatum did not change with different nitrogen sources, and there was the same time to reach the maximum diameter, at 55days in all experiment groups(Fig.9c).

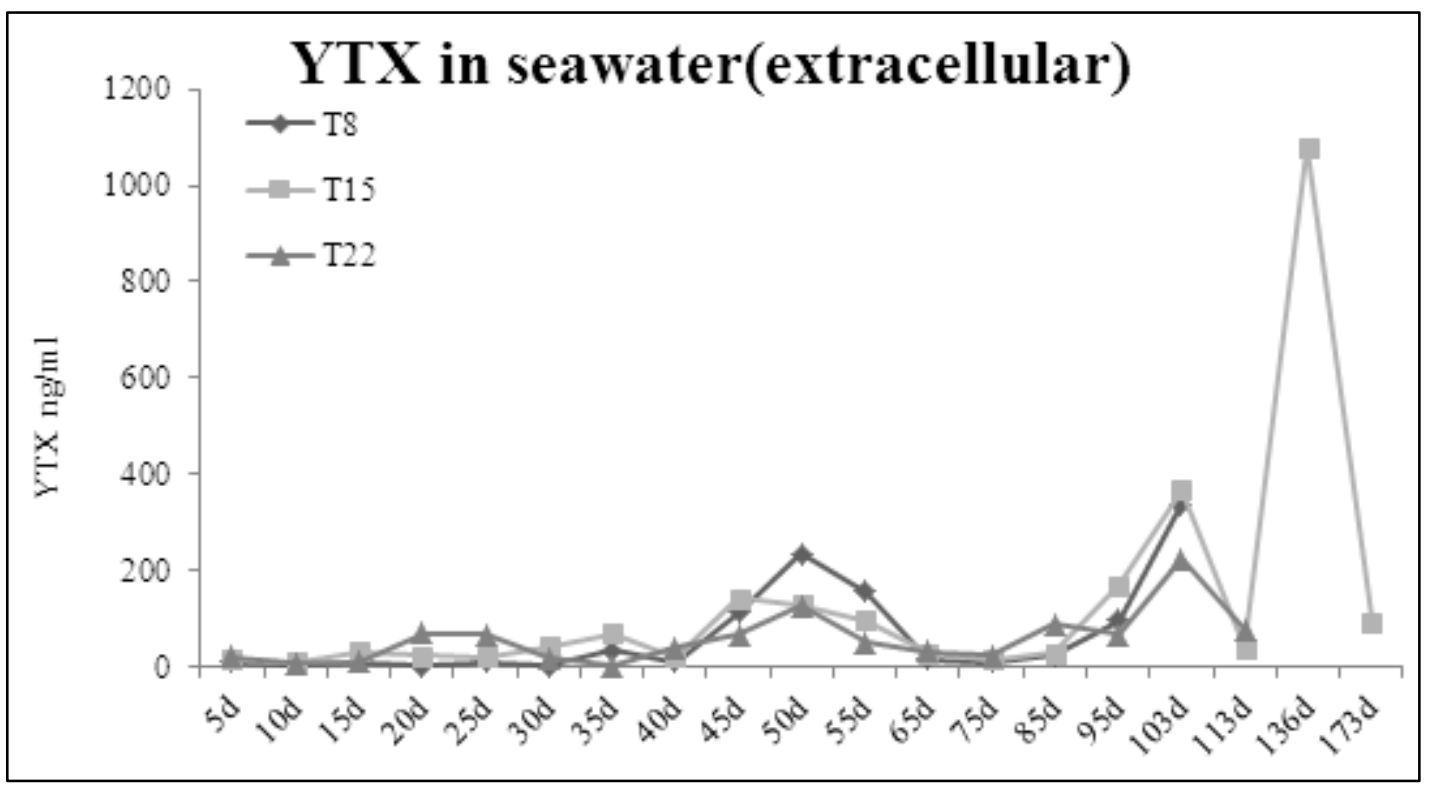

Figure 12. The YTX in seawater produced by $P$. reticulatum under different temperature

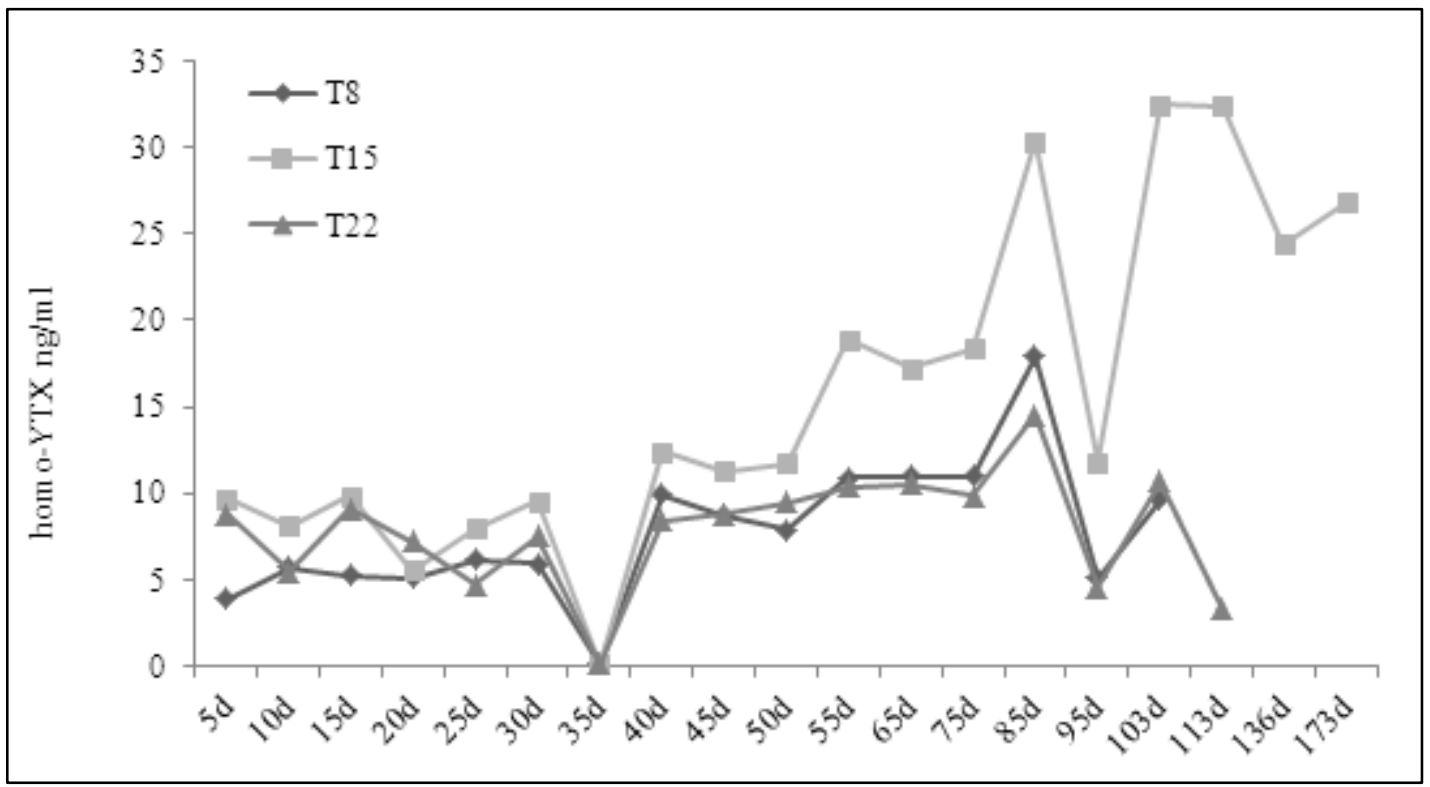

Figure 13. The homo-YTX inside cells produced by $P$. reticulatum under different temperature 
The most YTXs toxin existed inside the cells of $P$. reticulatum and only a little of YTXs was in seawater; the maximum ratio of extracellular and intracellular YTXs was about 5 times; at about 136d; YTXs produced by $P$. reticulatum under all four experiment groups all reached the highest amount with a maximum of $7.1 \mu \mathrm{g} / \mathrm{ml}$ (sum of YTXs inside and outside the cells) special under without nitrogen source; The amount of YTXs produced without nitrogen sources was higher than that in $\left(\mathrm{NH}_{2}\right)_{2} \mathrm{CO}, \mathrm{NH}_{4} \mathrm{NO}_{3}$ and $\mathrm{NH}_{4} \mathrm{Cl}$ (Fig.10c). There was lower YTXs both in $\mathrm{NH}_{4} \mathrm{Cl}$ and $\mathrm{NH}_{4} \mathrm{NO}_{3}$. In control group (in $\mathrm{NaNO}_{3}$ as nitrogen source), the trend of YTXs was similar to in $\left(\mathrm{NH}_{2}\right)_{2} \mathrm{CO}$ as nitrogen source, and without nitrogen sources, at 136days, YTXs increased sharply and exceeded the other four experimental groups special with $9.1 \mu \mathrm{g} / \mathrm{ml}$.

In conclusion, $\left(\mathrm{NH}_{2}\right)_{2} \mathrm{CO}$ was the most suitable nitrogen source for the growth of $P$. reticulatum; there was the most YTXs toxin produced in control $\left(\mathrm{NaNO}_{3}\right)$ while followed without nitrogen source; there was the most average YTXs toxin for a single cell in $\mathrm{NH}_{4} \mathrm{Cl}$ as nitrogen source(Fig.11c).

\subsubsection{The Growth and Production YTXs of P. reticulatum in Different Phosphorus Sources}

The density of $P$. reticulatum without phosphorus sources was far lower than the other four experiment groups, from 25 days, the cells started to decline and till 173days, there was no cell left. The density of $P$. reticulatum rose slowly and there was the highest density at 136days and then started to decline till all death under ATP as phosphorus source; the trends of density of $P$. reticulatum in adenosine phosphate, triple superphosphate, and without phosphorus sources and sodium dihydrogen phosphate, were all similar to that in ATP while the control group had the higher density with $31080 \mathrm{cells} / \mathrm{ml}$. The density of cells cultured without phosphorus source was much lower than that under other phosphorus sources, so the $P$. reticulatum is a kind of specie that depends on phosphorus sources(Fig.8d).The $P$. reticulatum's cell was not very different in size under different phosphorus source. The diameter of cells in without phosphorus sources was a little higher than that in other experimental groups, had the maximum at 55days. The biggest size of $P$. reticulatum all reached at 55days, no difference with different phosphorus sources(Fig.9d).

The maximum ratio of extracellular and intracellular YTXs produced $P$. reticulatum about 110 times; at about 136days, YTXs produced by $P$. reticulatum reached the highest amount with a maximum of $10.4 \mu \mathrm{g} / \mathrm{ml}$ (sum of YTXs inside and outside the cells) special under sodium dihydrogen phosphate (control experiment group); the amount of YTXs produced was decreased according to the following order: sodium dihydrogen phosphate $>$ without phosphorus $>$ triple superphosphate $>$ adenosine phosphate $>$ ATP(Fig.10d). There was the greatest YTXs for single cell produced by $P$. reticulatum which was cultured under without phosphorus source, while in ATP, adenosine phosphate and triple superphosphate groups, the YTXs was basically similar(Fig.11d).

\subsection{The Distribution and Fate of YTXs in each Level of the Ecosystem (Simulation Experiment in Laboratory)}

\subsubsection{YTXs in Shellfishes Increased along Time}

P. yessoensis was fed using 1L $P$. reticulatum every day till 16d, the YTX toxin in adductor muscle increased and reached to the maximum saturation value at about 6-9days, and almost did not change anymore; for YTX toxin in mantle, it reached to saturation at $11 \mathrm{~d}$ around, and for gill, YTX reached the maximum at about 14days; only in digestive glands, the YTXs continued to increase (Fig.14).

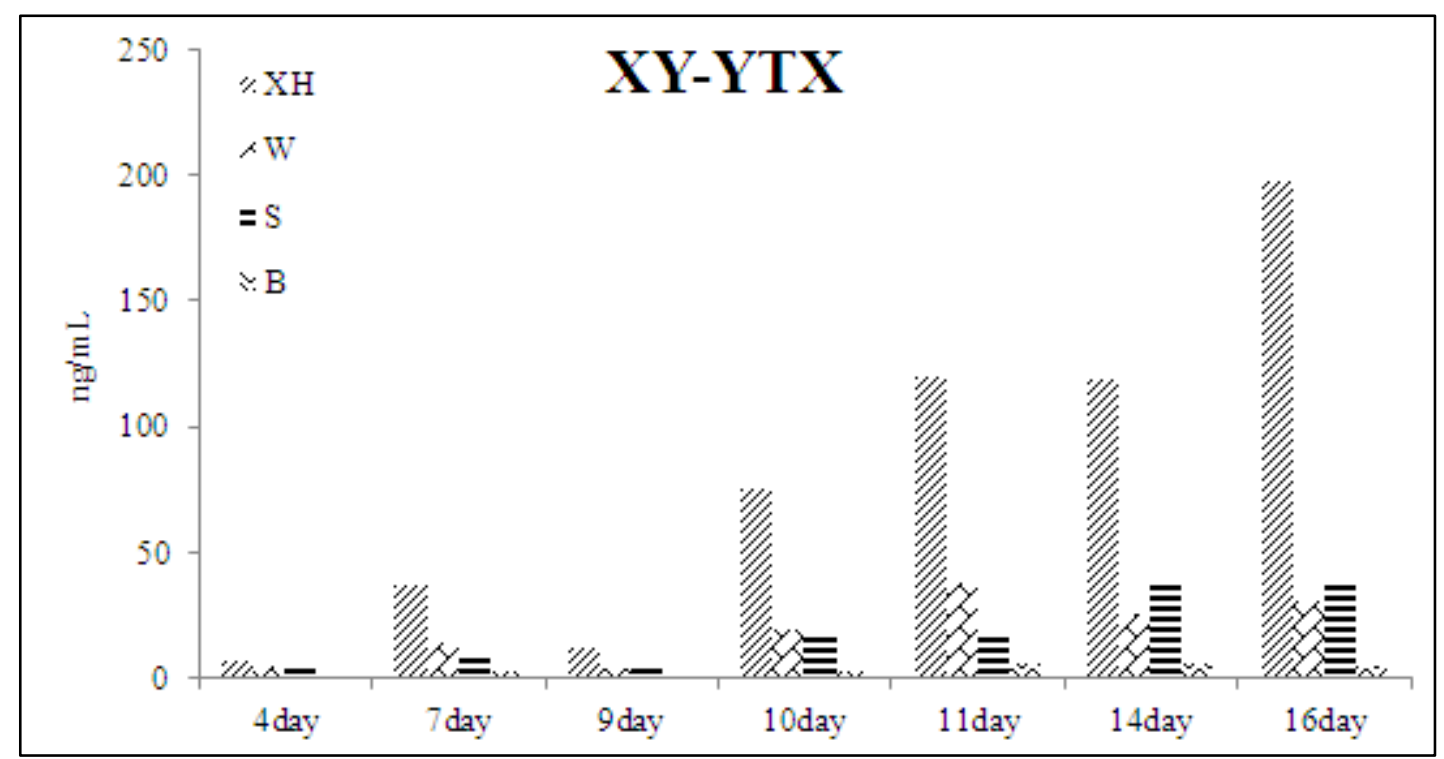

Figure 14. The YTXs in different organs of $P$. yessoensis(XH:digestive gland; W:mantle; S:gill; B:adductor muscle) 


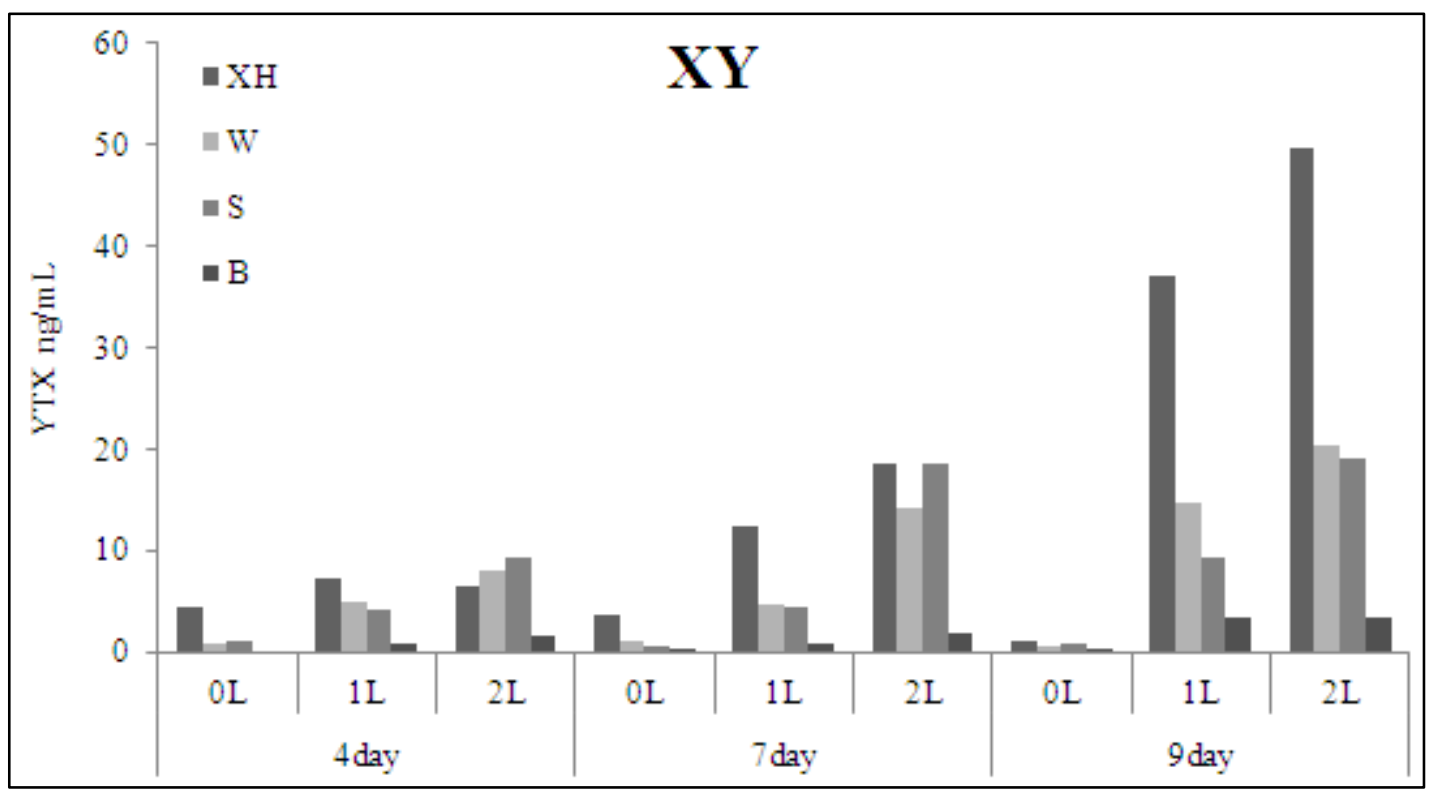

Figure 15. The YTX change in parts of $P$. yessoensis fed different amount of $P$. reticulatum(XH:digestive gland; W:mantle; S:gill; B: adductor muscle)

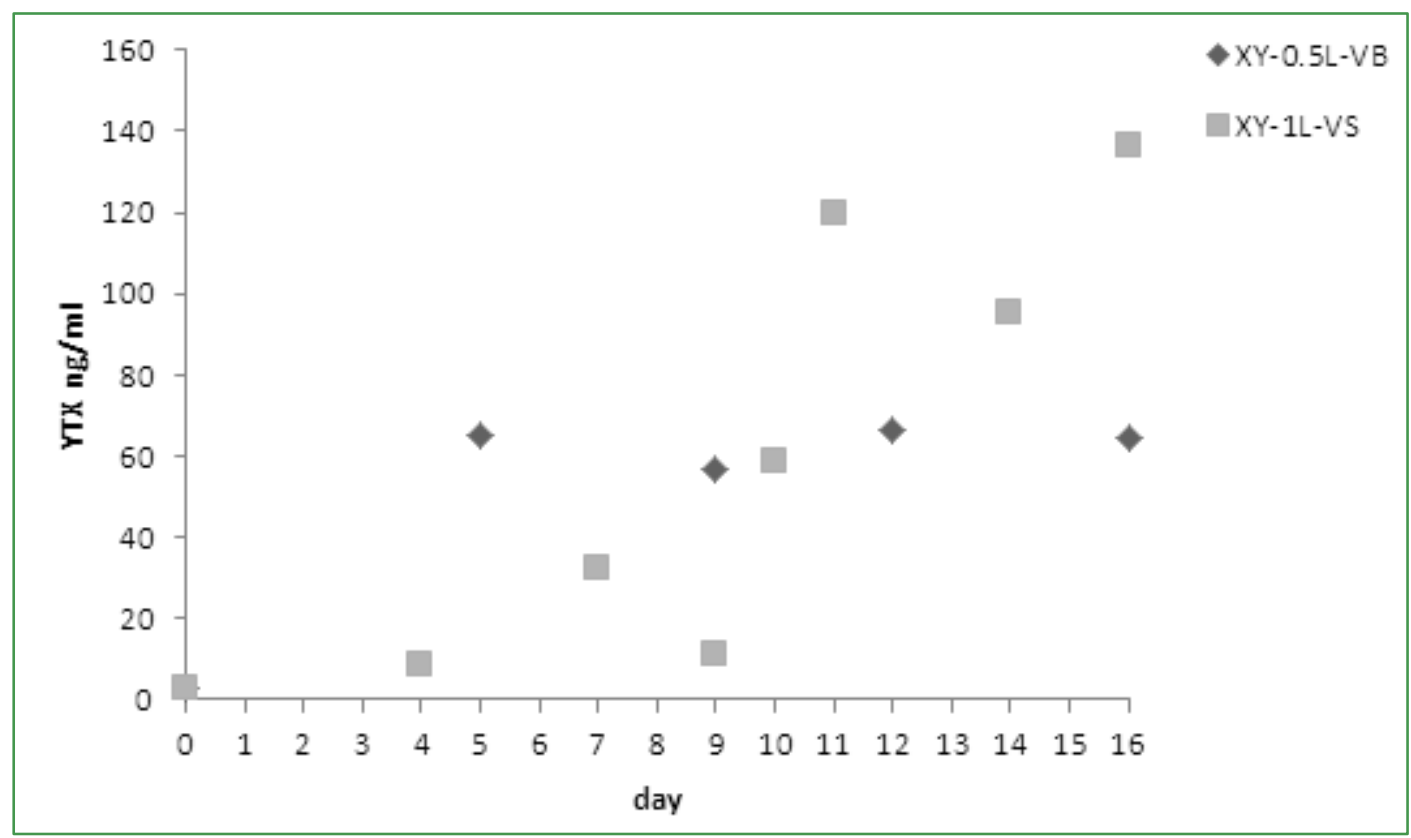

Figure 16. YTXs accumulated in $P$. yessoensis under smaller density (XY-0.5L-VB) and higher density(XY-1L-VS)

3.3.2. YTXs in P. yessoensis Increased with the Increasing of the Concentration of $P$. reticulatum Fed

$P$. yessoensis was fed using $1 \mathrm{~L}$ and $2 \mathrm{~L} P$. reticulatum till 9days. The YTX in $P$. yessoensis increased, and it had much toxin when fed $2 \mathrm{~L}$; the reduction of YTXs toxin a long time showed short-term cultivation in clean seawater could remove some of YTXs in shellfish(Fig.15).

\subsubsection{Short Term Feeding Experiment for $P$. yessoensis}

$P$. yessoensis(small, $2.1 \times 2.3 \mathrm{~cm}$ ) was fed using $P$. reticulatum(about 22500 cells/L). YTX in $P$. yessoensis reached peak level at 5 days, and then was basically no longer increased with time(Fig.16). When the density of feeding $P$. reticulatum (89800cells/L)was four times as high, the YTX in P. yessoensis was at about 11 days to reach the maximum value, but YTX level would be higher(Fig.16). The higher density of toxic $P$. reticulatum was fed, the more toxins in the $P$. yessoensis were detected. In conclusion: YTXs in $P$. yessoensis depends on the density of toxic algae in surrounding environment.

\subsubsection{The YTXs Accumulated (feeding toxic P. reticulatum) and Eliminated (Feeding Bait Algae) in Mussel}

When the mussels(large, $6.6 \times 3.5 \mathrm{~cm}$ ) were fed using toxic $P$. reticulatum, YTXs in mussel increased quickly from 5-8days and reached to the peak at about 10days; at 14days, fed using nontoxic bait algae(Isochrysis galbana).The YTXs started to decline, but it was slow down(Fig.17). 


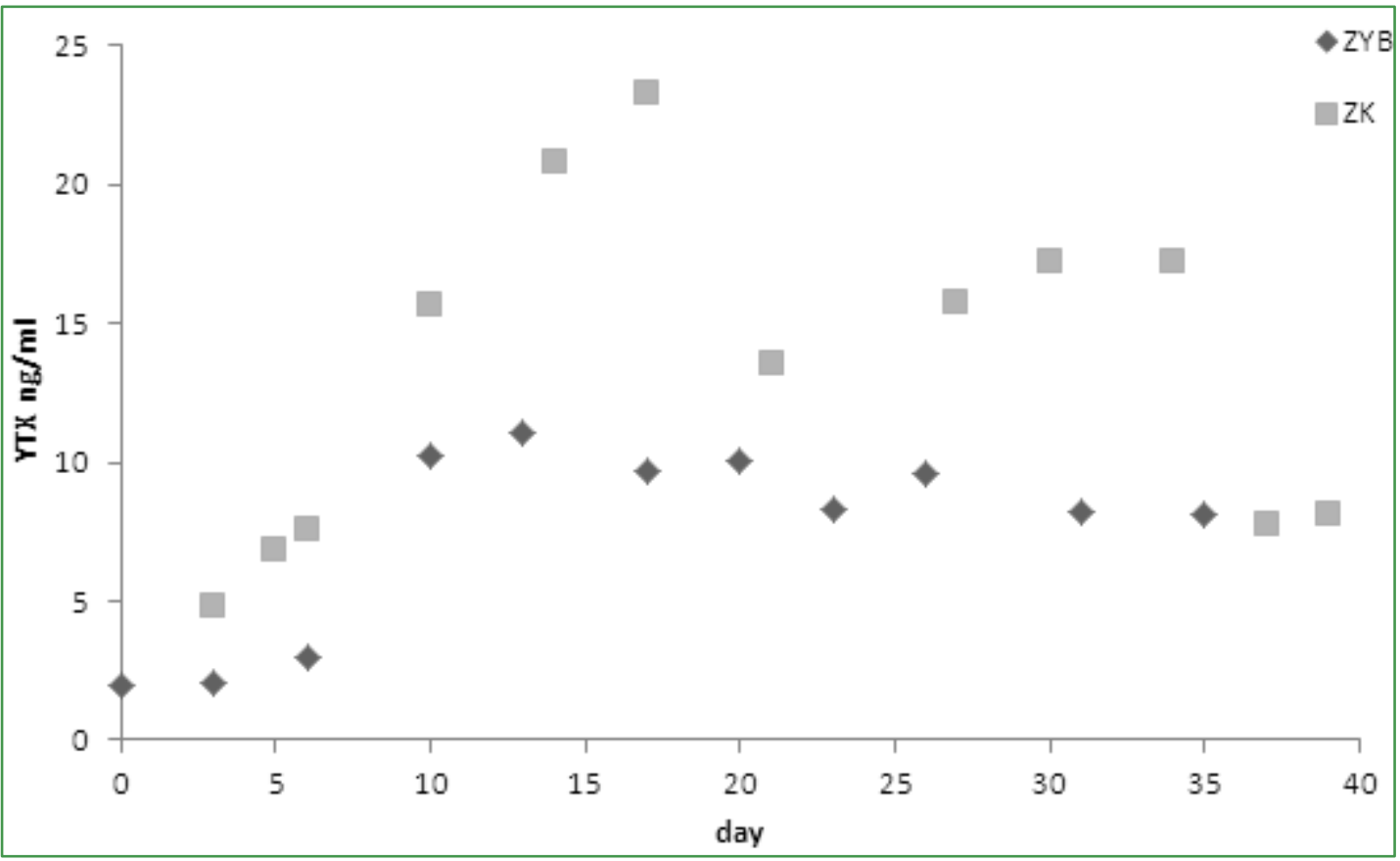

Figure 17. The YTXs accumulated and eliminated in mussels(ZYB) and C. farreri(ZK)

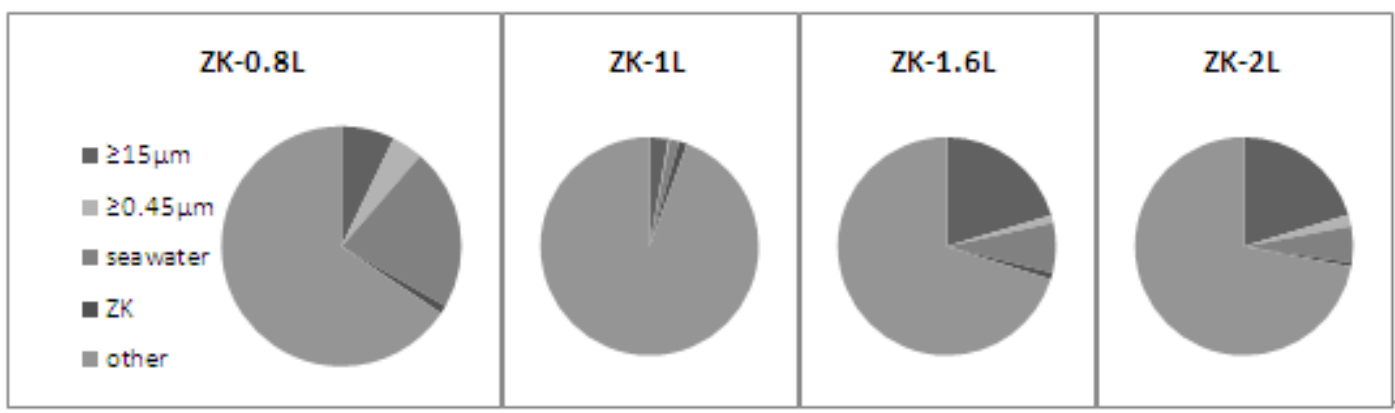

Figure 18. The distribution of YTXs in each midium of the system which C. farreri fed using P. reticulatum(3days)

3.3.5. The Distribution, Accumulation and Elimination of YTXs in $C$. farreri

After 20days the $C$. farreri (small, $2.75 \times 2.38 \mathrm{~cm}$ ) was fed using toxic $P$. reticulatum, changed feeding only using nontoxic bait algae at the twentieth day, YTX in $C$. farreri started to reduce after stopping feeding toxic $P$. reticulatum, the change trend was similar to that in the mussel, and YTX in $C$. farreri had a significant reduction at the last 37 days (Fig. 17).

\subsubsection{The Distribution Experiment of YTXs in System} When $C$. farreri Fed Using $P$. reticulatum(Three Days)

C. farreri (large, $6.62 \times 6.06 \mathrm{~cm}$ ) was fed with different volumes of $P$. reticulatum for 3 days. As it could be seen(showed in Fig.18), YTXs distributed mainly in particulate matters $(\mathrm{PM})$ with a diameter $\geq 15 \mu \mathrm{m}$; only in experiment group with a minimum volume of $0.8 \mathrm{~L}$, YTXs distributed mainly in seawater and the second was in $\operatorname{PM}(\geq 15 \mu \mathrm{m})$; and the YTXs toxin in shellfish was a little with a proportion of $1 \%$ around. YTXs Toxin that was detectable was only about $1 / 4$ of total YTXs added, the most of YTXs toxin converted into undetectable structures (this method can only analyze 5 structures).

\subsubsection{The Distribution of YTXs in $C$. farreri and $P$. yessoensis Ecosystem (1 day)}

After 24hours, when $C$. farreri and $P$. yessoensis were fed using $P$. reticulatum, in these small experiment ecosystems, the YTX structure was all a dominant structure in each medium both value and detection rate, and then the detection rate of homo-YTX was higher than that of 45-OH-YTX while its value was lower than $45-\mathrm{OH}-\mathrm{YTX}$ both $C$. farreri and $P$. yessoensis; there was more rapidly transformation in digestive gland for YTXs, that Carboxy-YTX structure existed in digestive gland of two scallops showed the YTXs structures transformed was diversified and complex in the digestive gland. 


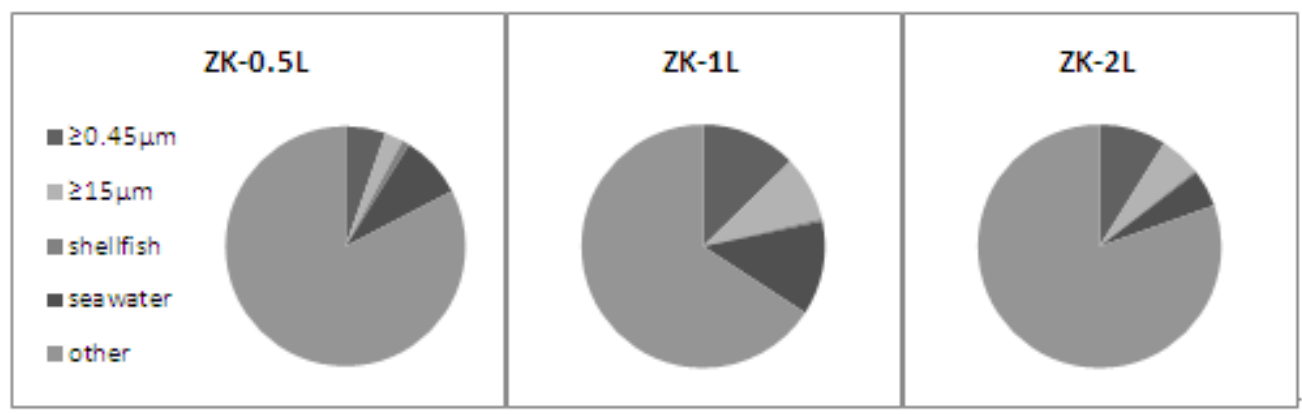

Figure 19. The distribution of YTXs which $C$. farreri fed under different volumn of $P$. reticulatum(1day)

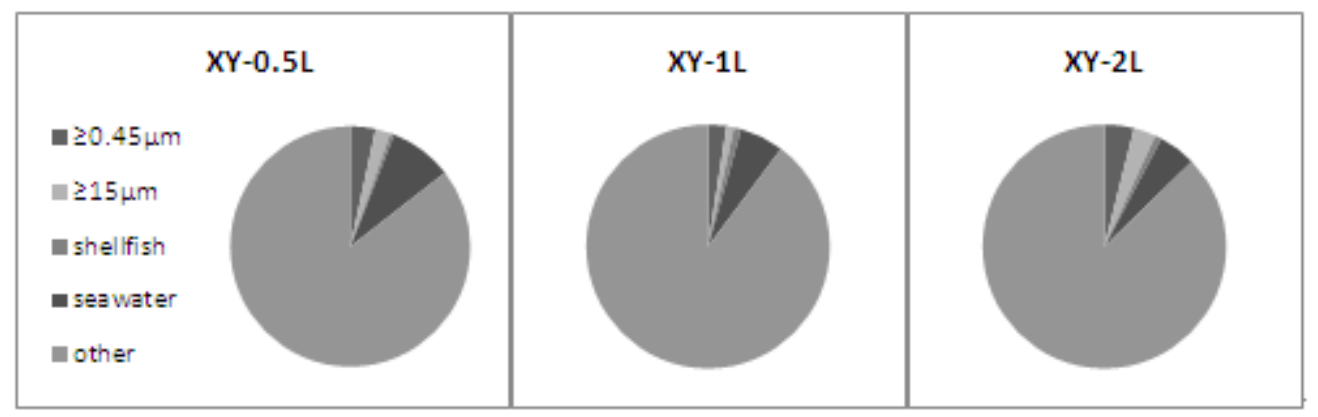

Figure 20. The distribution of YTXs which P. yessoensis feeded under different volumn of $P$. reticulatum(1day)

The vast majority of YTXs existed in particulate matters and seawater while it had much YTXs toxin in $15 \mu \mathrm{m} \sim$ $0.45 \mu \mathrm{m}$ size of $\mathrm{PM}$ than that in $\mathrm{PM}$ with $\geq 15 \mu \mathrm{m}$ size also for the two scallops; YTXs in C. farreri was rare with a proportion of 1\% less (showed in Fig.19),but special with a percentage of $1 \%$ around for $P$. yessoensis group; while it had a proportion of $5 \% \sim 13 \%$ in seawater special for $C$. farreri, but of $5 \% \sim 9 \%$ in seawaters for $P$. yessoensis (Fig. 20); all detectable YTXs only took a $1 / 4$ around of the total YTXs added for $C$. farreri, and $1 / 8$ for $P$. yessoensis, and the most YTXs added rapidly transformed into undetectable structures.

\subsubsection{The Distribution of YTXs in Different Parts of Shellfish}

The concentration of YTXs in different parts of $C$. farreri was directly proportional to the amount of $P$. reticulatum added; YTXs in the digestive glands, mantle, sex gland and adductor muscle was decreasing; although there was the minimum concentration of YTXs in adductor muscle of $C$. farreri, but due to the huge weight it might contain higher YTXs than other parts(Fig.21). The YTXs profile in the digestive glands of $C$. farreri was most complex, only in digestive glands 45-OH-YTX existed besides YTX and homo-YTX; YTX was always an absolute dominant structure in each organ (Fig.22).

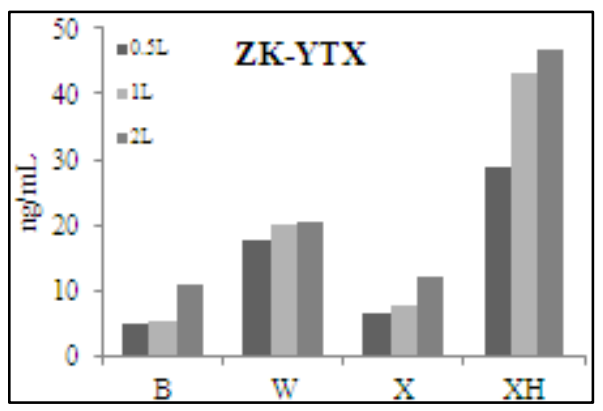

Figure 21. YTX in different parts of $C$. farreri XH: digestive gland; W: mantle; X:sex gland; B: adductor muscle

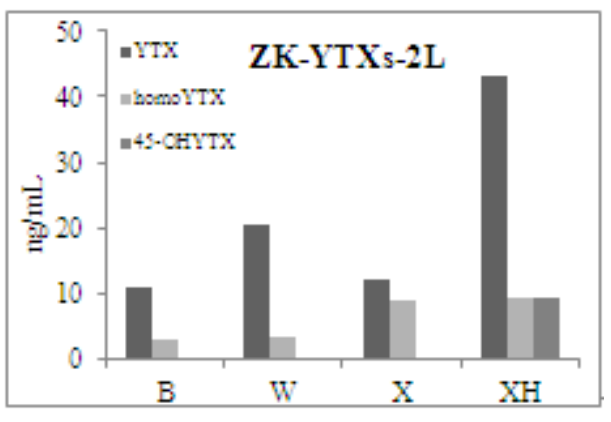

Figure 22. YTXs profile in different parts of $C$. farreri

The features of YTXs in $P$. yessoensis fed using $P$. reticulatum were same with those in $C$. farreri, only difference was that Carboxy-YTX structure also found in a digestive glands sample (Fig. 23 and Fig. 24). 


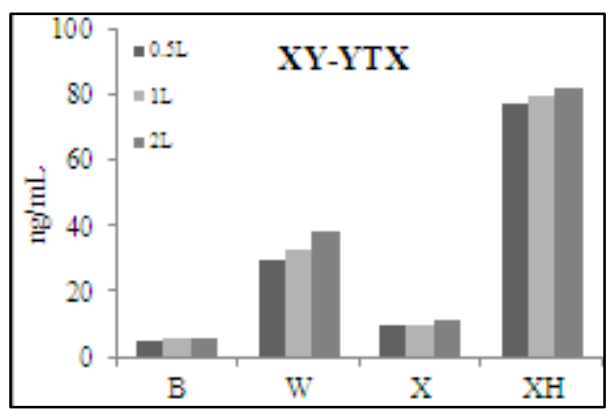

Figure 23. YTX in different parts of $P$. yessoensis

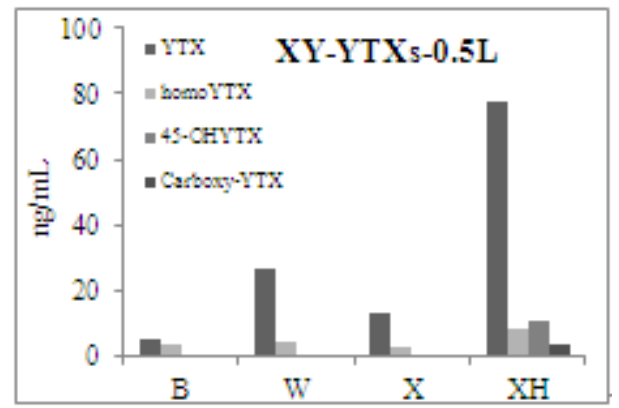

Figure 24. YTXs structure in different parts of $P$. yessoensis

3.3.9. The Accumulation of YTXs in Different Shellfish

P. yessoensis $(7.2 \times 7.4 \mathrm{~cm})$ and $C$. farreri $(5.6 \times 6.2 \mathrm{~cm})$ were fed with $1 \mathrm{~L}, 2 \mathrm{~L}$ and $3 \mathrm{~L}$ toxic $P$. reticulatum $(2500$ cells $/ \mathrm{ml})$, the content of YTXs was analysed at the first, third and fifth day.

The YTXs in different parts of $P$. yessoensis and $C$. farreri was becoming rising with the increase of toxic $P$. reticulatum fed and the longer of feeding experiment (Fig.25 and 26). There were YTX, homo-YTX, 45-OH-YTX and Carboxy-YTX existed in $P$. yessoensis, but it was 45-OH-homoYTX structure instead of Carboxy-YTX in $C$. farreri experiment. The amount of YTX in the $C$. farreri was lower than that in $P$. yessoensis, probably because $P$. yessoensis had a large size and a stronger ability to enrich YTXs.

\subsection{The Distribution of YTXs in P. yessoensis Ecosystem}

YTXs in particulate matter $(\geq 0.45 \mu \mathrm{m})$ and seawater was all increasing along time when $P$. yessoensis $(4.1 \times 3.9 \mathrm{~cm})$ were cultured in different density of toxic $P$. reticulatum, no matter in low density (1L)or in high density(2L);YTXs in shellfishes reached to the maximum at the sixth day and then started to drop after saturation; YTXs in PM with a $\geq 0.45 \mu \mathrm{m}$ grain size increased a lot in a big density of toxic algae; YTXs in $P$. yessoensis only took about $1 \%$ proportion no matter the density of $P$. reticulatum fed was high or low; the proportion of undetectable YTXs structures was more rapidly decrease along time in high density than that in low density(Fig.27).

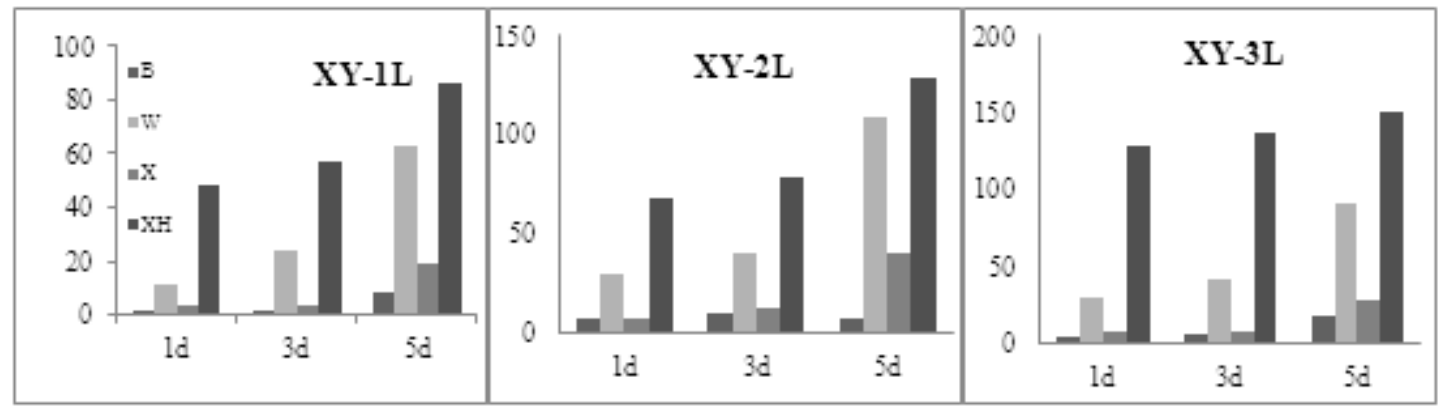

Figure 25. YTX $(\mathrm{ng} / \mathrm{ml})$ in $P$. yessoensis fed different volumn of $P$. reticulatum

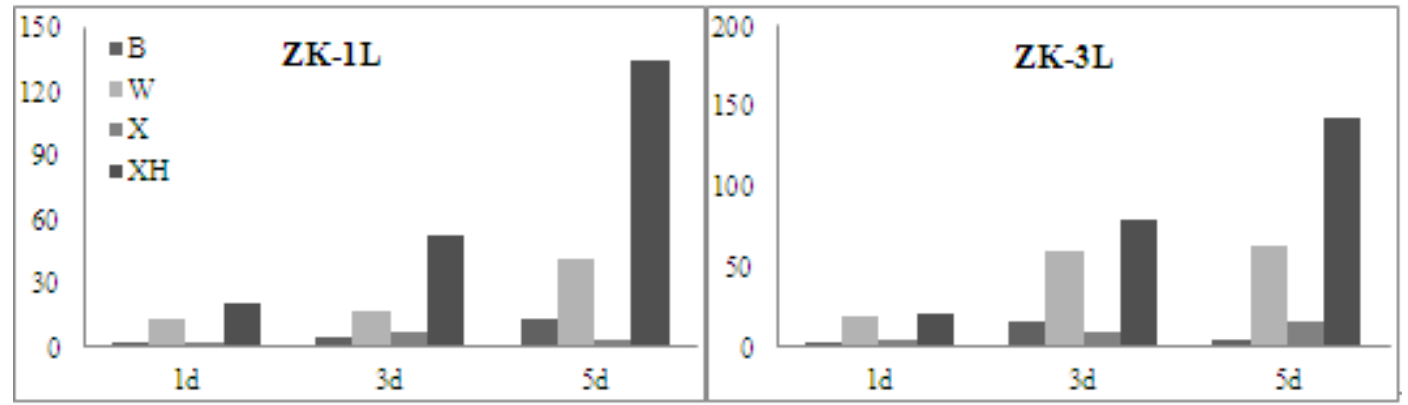

Figure 26. YTX in C. farreri fed different volumn of $P$. reticulatum 


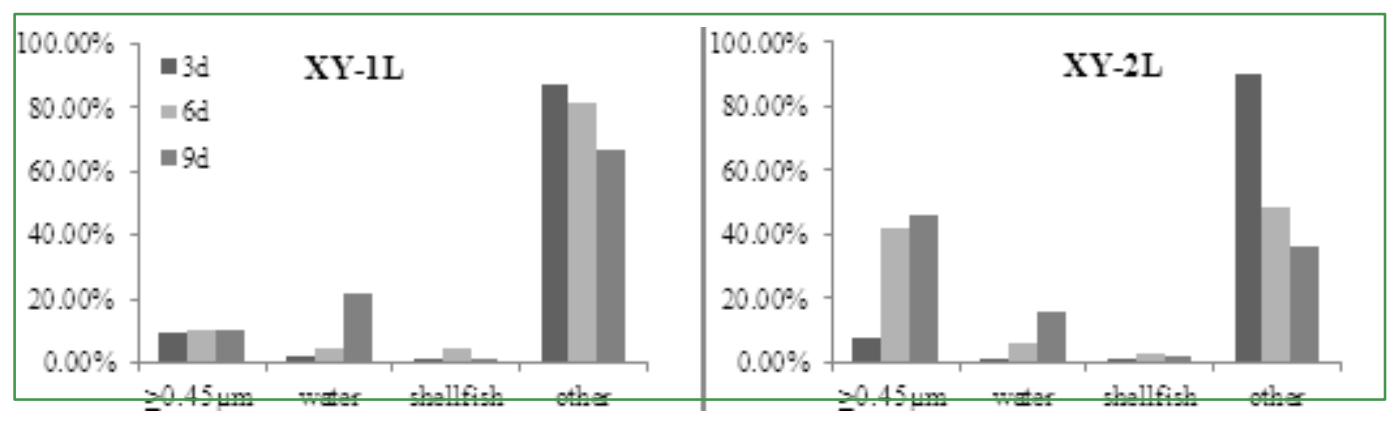

Figure 27. YTX in P. yessoensis cultured in different $P$. reticulatum

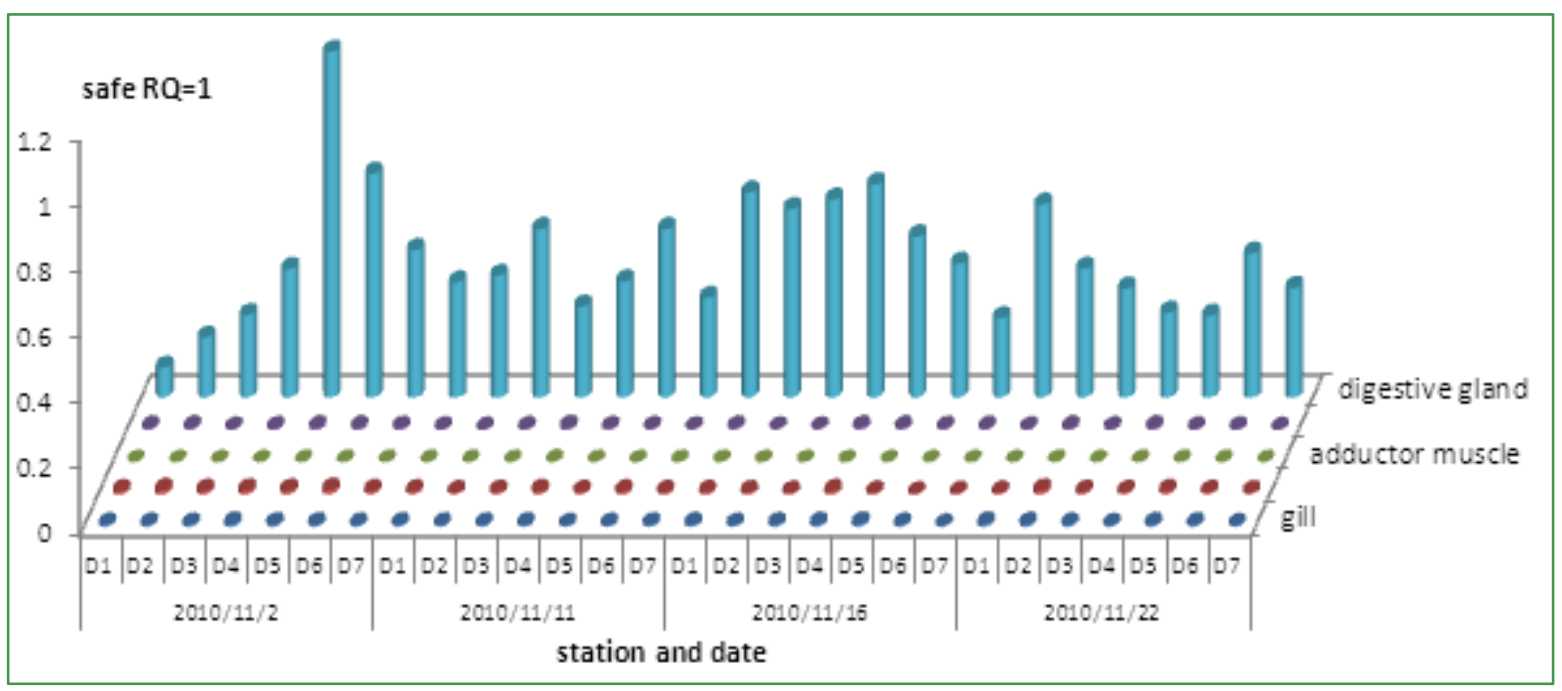

Figure 28. Assessment risk of YTX in $P$. yessoensis's different parts

\subsection{The Potential Ecological Risk Assessment on Shellfish Aquiculture Area in the Northern Yellow Sea Area}

The northern Yellow Sea of China is a potential coastal area which has already been threatened by YTXs. The three species of dinoflagellates which could produce YTXs all existed in this coastal waters, especially the $P$. reticulatum, produced high YTXs toxin. It could bloom quickly to reach a very higher abundance under the suitable ecological environment; YTXs accumulated in shellfishes, the level in several mussels and $C$. farreri already exceeded the safety threshold, the risks of health must be paid attention to; the most YTXs mainly existed in seawater and particulates, and although the level was very low in seawater, but what's more? Most YTXs toxin could fast transform into unknown structures. A few structures of YTXs which are known have small oral toxicity, so that it can regard the ecological function as a shellfish aquiculture area for the northern Yellow Sea area is still good. YTXs toxin can be eliminated by removing the digestive glands (Fig 28) and cultivating toxic shellfish in clean seawater for short time. The health risk can most likely be controlled by reinforcing the detection of the shellfish and the planktons; but the potential ecological risk of YTXs toxin cannot be ignored in the northern Yellow Sea coast, More and deep study on YTXs toxicology should be carry out, especially on other YTXs structures, and the toxicity of YTXs on other coexist creatures in ecosystem. Only in this way, the ecological risk grade of YTXs can be accurate evaluated.

\section{Discussion}

This work reveals that $P$. reticulatum is one of the major producers for YTXs in the northern Yellow sea of China. The other two species of dinoflagellates, L. polyedrum and $G$. spinifera, which can also produce YTXs, have also been found to exist there. L. polyedrum and $G$ spinifera may also contribute to production of YTXs in there, but their contribution must be less than $P$. reticulatum from results of this study.

The abundance change of toxic dinoflagellates was same with the trend of YTXs in plankton, and the peak time of YTXs in seawaters and shellfish slightly lags behind the highest abundance time of toxic dinoflagellates, and the peak time of YTX in cyst appeared in advance of the highest abundance time of toxic dinoflagellates. It may be inferred that rapid gathering and germination of the cysts resulted in increased abundance of toxic algae, and toxic algae directly contributed the YTXs toxin in plankton. P. reticulatum was widely spread in the northern Yellow Sea of China, while the L. polyedrum was rarely found. This is also the first report of moving cells of $P$. reticulatum found in China coast waters. 
There was the highest abundance of $P$. reticulatum at $\mathrm{D}$ site in April 2013, special with very high density of 47550 cells/ml, and it was every April when $P$. reticulatum reached the maximum abundance; the months of the maximum abundance for $G$. spinifera was slightly different in different years in D site. It was March both in 2011 and 2012, but it was April in 2013 with the maximum abundance of 7910 cells/ml. The spring was the season of toxic dinoflagellates bloom in the northern Yellow Sea anyway.

The YTXs varied according to the species of bivalve mollusk. The oyster had the lowest YTXs while it was far higher in $P$. yessoensis and C. farreri than that in the oyster. At the same time, the content of YTXs in $C$. farreri was a little higher than that in P. yessoensis for the most stations.

One clonal isolate of $P$. reticulatum was collected from plankton samples in Dalian's coastal waters in February 2014. The sequence of the clonal isolate of $P$. reticulatum from Dalian coast had been identified to be almost same with the Japanese strain of $P$. reticulatum from GenBank(see another paper). The density of $P$. reticulatum cultured reached the maximum at $15^{\circ} \mathrm{C}$ temperature and $20 \%$ salinity. The arctic $P$. reticulatum also had the maximum growth rate at $15^{\circ} \mathrm{C}$ temperature [5].

This strain of $P$. reticulatum in this study revealed toxin profiles which are consistent with those of the arctic isolate and most other isolates from the Atlantic with more than 95\% YTX of total YTXs content being the most abundant congener[5], and also contains a little homo-YTX congener; the most YTXs toxin existed inside the cells and only a little of YTXs existed outside the cells, in the culture medium or seawater. The maximum production of YTXs by $P$. reticulatum cultured can also reach at $15^{\circ} \mathrm{C}$ temperature and $30 \%$ salinity.

The $P$. reticulatum grew the best in urea as nitrogen source, and YTXs produced reached the maximum special under without nitrogen source and under sodium dihydrogen phosphate as phosphate source at about 136days. The results depending density of cells, that $P$. reticulatum still grew quite well and had the highest density at 65days with $28000 \mathrm{cells} / \mathrm{ml}$ under without nitrogen source, and the density special in without phosphate was far lower than that in adenosine triphosphate, adenosine phosphate, triple superphosphate and sodium dihydrogen phosphate, indicated this clonal isolate of $P$. reticulatum was not a specie of limited by nitrogen source, but different nitrogenous compounds had much different affection on its growth, and was a kind of specie stronger depending on phosphorus sources, and different phosphorus compounds had not much different affection on its growth.

The cell size was all reaching to the maximum at 55 days, which was to say, the peak time of the maximum diameter of $P$. reticulatum's cell did not change within different temperature, salinity, nitrogen and phosphorus source, but different phosphorus source slight but significantly affected cell size.

The results in this study showed that YTX for single cell of $P$. reticulatum cultured ranged from 8.2 to $54.4 \mathrm{pg}$ YTX cell $^{-1}$. But for different nitrogen and phosphorus source experiment groups, YTX in single cell may be more than hundreds, even more than one thousand pg YTX cell ${ }^{-1}$ in two samples. There was the most YTXs toxin for a single cell in ammonium chloride $\left(\mathrm{NH}_{4} \mathrm{Cl}\right)$ and without phosphorus experimental groups. There was the minimum of YTXs when $P$. reticulatum cultured in ATP phosphorus source, and while that was the maximum YTXs in $\mathrm{NaH}_{2} \mathrm{PO}_{3}$, and the most YTXs toxin produced in $\mathrm{NaNO}_{3}$ as nitrogen source. Inorganic forms of nitrogen and phosphorus might be more conducive to the production of YTXs toxins for $P$. reticulatum, which need more and deeply study.

The results of feeding shellfish using this clonal of $P$. reticulatum showed that the most detectable YTXs existed in particulate matters and seawaters.Only about $1 \%$ percentage of YTXs added was been found in shellfish, the total amount of YTXs detectable was much lower than YTXs added, with $1 / 4$ around specific for $C$. farreri and 1/8 around specific for P. yessoensis. The analytical method used for YTXs in this study can only analyze five structures of YTXs. They are YTX, homo-YTX, 45-OH-YTX, Carboxy-YTX and 45-OH-homoYTX. It can be deduced the most YTXs fed had been fast transformed into other structures except above five congeners in $24 \mathrm{~h}$. Moreover, it is no doubt that the complex biochemical substances in the digestive gland of shellfish accelerate the transformation rate, and also make the transformation process more sophisticated. The diversity of YTXs structure in digestive gland was the best proof. Comparing the YTXs distribution feature in the small ecosystem of $P$. yessoensis and $C$. farreri fed, the longer when $P$. yessoensis and $C$. farreri had been fed, the more YTXs existed in particles with a large size; the percentage of YTXs in seawater also was very significant. No matter $P$. yessoensis or $C$. farreri, the YTXs toxin in shellfish was becoming more with the increase of density of toxic dinoflaglate in the surrounding. $P$. yessoensis had a stronger ability of enrichment of YTXs than the $C$. farreri, which might be due to their great size, or because the difference between species.

Although the harm of phycotoxin on human beings was brought about mainly through accumulation in shellfish, but the truth is that the phycotoxin in shellfish only occupy a very small proportion, and then potential threat and change of the great phycotoxin existence in other media, particular matters and seawaters, on the whole ecosystem is what? In addition, it is very difficult to know exactly how each congener of toxicology, which also creates a great difficulty for the answer of above problem, based on the complexity and diversity of spices and structure of phycotoxins. This is the reminder and warns of the results of YTXs study above.

In brief, the presence of the toxic dinoflagellate, $P$. reticulatum, which can produce YTXs on the coast of the northern Yellow Sea of China, was confirmed and the first clonal cultures of this species from Dalian seawaters were established. It seems to support $P$. reticulatum as a bloom forming species in there. Temperature, salinity, different nitrogenous and phosphorus compounds have showed the 
considerable or obvious effects on the growth and production YTXs of $P$. reticulatum. In the marine ecosystem of the northern Yellow Sea of China, for YTXs of $P$. reticulatum, a significant amount may exist in particulate matters and also seawater, and then what is its potential damage and threats to whole ecosystem which must be paid attention.

\section{Acknowledgements}

We greatly acknowledge the financial support of National Natural Science Foundation of China, projects No.41176086, 41276099 and 41576120.

\section{REFERENCES}

[1] Murata, M., Kumagai, M., Lee, J. S., Yasumoto, T., 1987, Isolation and structure of yessotoxin, a novel polyether compound implicated in diarrhetic shellfish poisoning. Tetrahedron Lett. 28(47), 5869-5872.

[2] Gao, C.L., Liu, R.Y., Liang, Y.B., Wang, Z., Liu, Y., Pang, M., Zhang, F., Pan, N., Xu, D., Shao, K., 2010, First report of the presence of yessotoxins (YTXs) in shellfish from China's coastal areas. Acta Oceanol. Sin. 3(129-137.

[3] Howard, M.D., Silver, M., Kudela, R.M., 2008, Yessotoxin detected in mussel (Mytilus californicus) and phytoplankton samples from the US west coast. Harmful Algae. 7(5), 646-652.

[4] Li, A., Chen, H., Qiu, J., Lin, H., Gu, H., 2016, Determination of multiple toxins in whelk and clam samples collected from the Chukchi and Bering seas. Toxicon. 109,84-93.

[5] Sala-Pérez, M., Alpermann, T.J., Krock, B., Tillmann, U., 2016, Growth and bioactive secondary metabolites of arctic Protoceratium reticulatum (Dinophyceae). Harmful Algae. 55(85-96.

[6] Fernández-Araujo, A., Alfonso, A., Vieytes, M.R., Botana, L.M., 2015, Yessotoxin activates cell death pathways independent of Protein Kinase C in K-562 human leukemic cell line. Toxicol. In Vitro. 29(7), 1545-1554.

[7] Rubiolo, J.A., López-Alonso, H., Martinez, P., Millán, A., Cagide, E., Vieytes, M.R., Vega, F.V., Botana, L.M., 2014, Yessotoxin induces ER-stress followed by autophagic cell death in glioma cells mediated by mTOR and BNIP3. Cell. Signal. 26(2), 419-432.

[8] Paz, B., Daranas, A.H., Norte, M., Riobó, P., Franco, J.M., Fernández, J.J., 2008, Yessotoxins, a group of marine polyether toxins: an overview. Mar. Drugs. 6(2), 73-102.

[9] Miles, C.O., Samdal, I.A., Aasen, J.A., Jensen, D.J., Quilliam, M.A., Petersen, D., Briggs, L.M., Wilkins, A.L., Rise, F., Cooney, J.M., 2005, Evidence for numerous analogs of yessotoxin in Protoceratium reticulatum. Harmful Algae. 4(6), 1075-1091.
[10] Ogino, H., Kumagai, M., Yasumoto, T., 1997, Toxicologic evaluation of yessotoxin. Natural Toxins. 5(6), 255-259.

[11] Ciminiello, P., Dell'Aversano, C., Fattorusso, E., Forino, M., Magno, S., Guerrini, F., Pistocchi, R., Boni, L., 2003, Complex yessotoxins profile in Protoceratium reticulatum from north-western Adriatic sea revealed by LC-MS analysis. Toxicon. 42(1), 7-14.

[12] Satake, M., MacKenzie, L., Yasumoto, T., 1997, Identification of Protoceratium reticulatum as the biogenetic origin of yessotoxin. Natural Toxins. 5(4), 164-167.

[13] Satake, M., Ichimura, T., Sekiguchi, K., Yoshimatsu, S., Oshima, Y., 1999, Confirmation of yessotoxin and 45, 46, 47 - trinoryessotoxin production by Protoceratium reticulatum collected in Japan. Natural Toxins. 7(4), 147-150.

[14] Draisci, R., Ferretti, E., Palleschi, L., Marchiafava, C., Poletti, R., Milandri, A., Ceredi, A., Pompei, M., 1999, High levels of yessotoxin in mussels and presence of yessotoxin and homoyessotoxin in dinoflagellates of the Adriatic Sea. Toxicon. 37(8), 1187-1193.

[15] Paz, B., Riobó, P., Fernández, M.L., Fraga, S., Franco, J.M., 2004, Production and release of yessotoxins by the dinoflagellates Protoceratium reticulatum and Lingulodinium polyedrum in culture. Toxicon. 44(3), 251-258.

[16] Rhodes, L., McNabb, P., De Salas, M., Briggs, L., Beuzenberg, V., Gladstone, M., 2006, Yessotoxin production by Gonyaulax spinifera. Harmful Algae. 5(2), 148-155.

[17] Stobo, L.A., Lewis, J., Quilliam, M.A., Hardstaff, W.R., Gallacher, S., Webster, L., Smith, E., McKenzie, M., 2003, Detection of yessotoxin in UK and Canadian isolates of phytoplankton and optimization and validation of LC-MS methods. Can. Tech. Rep. Fish. Aquat. Sci./Rapp. Tech. Can. Sci. Halieut. Aquat.2498), 8-14.

[18] Aasen, J., Samdal, I.A., Miles, C.O., Dahl, E., Briggs, L.R., Aune, T., 2005, Yessotoxins in Norwegian blue mussels (Mytilus edulis): uptake from Protoceratium reticulatum, metabolism and depuration. Toxicon. 45(3), 265-272.

[19] Suzuki, T., Horie, Y., Koike, K., Satake, M., Oshima, Y., Iwataki, M., Yoshimatsu, S., 2007, Yessotoxin analogues in several strains of Protoceratium reticulatum in Japan determined by liquid chromatography-hybrid triple quadrupole/linear ion trap mass spectrometry. J. Chromatogr. A. 1142(2), 172-177.

[20] Lan, D.Z., Li, C., Fang, Q., 2005, A preliminary taxonomic study on dinoflagellate cysts from sediments of main estuary and bays in Fujian Province. China. 27(2), 70-78.

[21] MacKenzie, L., Holland, P., McNabb, P., Beuzenberg, V., Selwood, A., Suzuki, T., 2002, Complex toxin profiles in phytoplankton and Greenshell mussels (Perna canaliculus), revealed by LC-MS/MS analysis. Toxicon. 40(9), $1321-1330$.

[22] Matsuoka K, Fukuyo Y. Technical guide for modern Dinoflagellate Cyst study. Tokyo, Japan Society for the Promotion of Science, 2000:10.

[23] EU-RL-MB，2011. EU-Harmonised Standard Operating Procedure for Determination of Lipophilic Marine Biotoxins in Molluscs by LC-MS/MS. 